\title{
Bir Kur’ân Öğretim Modeli Olarak “3 Günde Kur’ân Öğreten Program”
}

\author{
“Qur’ān Teaching Programme in 3 Days” As A Qur’ān Teaching \\ Model
}

\section{Umut KAYA*}

Öz: Kur'ân-ı Kerîm, hem Allah'ın vahyi olmasından hem de okunması ibadet kabul edildiğinden, İslâm’ın doğuşundan itibaren Müslümanlar tarafından öğretimine büyük önem verilmiştir. Bu araştırmanın temel konusu, bir Kurân-1 Kerîm öğretim faaliyeti olarak “3 Günde Kur’ân Öğreten Program”ıdır. Araştırma bu program hakkındaki anket verilerine ve gözlem sonuçlarına dayalı olarak gerçekleştirilmiştir. Bu doğrultuda program başlangıcından bitimine kadar gözlemlenmiş ve katılımcılara 27 sorudan oluşan bir anket uygulanmıştır. Araştırmada, “3 Günde Kurân Öğreten Program” katılımcıların yaş, cinsiyet, öğretim seviyesi, sosyo-ekonomik durum, Kurân-1 Kerîm okuma seviyesi ve program hakkındaki düşünceleri bakımından incelenmiştir. Program sürecinde yapılan gözlemlere ve SPSS programında değerlendirilen anket sonuçlarına ve program sürecinde yapılan gözlemlere göre, " 3 Günde Kur'ân Öğreten Program”n Kur'ân-1 Kerîm öğretimi konusunda başarılı bir örnek olduğu söylenebilir.

Anahtar Kelimeler: Kurân Öğretimi, Kurân-1 Kerîm Öğretimde Yöntem ve Teknikler, 3 Günde Kurân Öğreten Program, Yetişkinler İçin Kurân-1 Kerîm Öğretimi

\begin{abstract}
The reading of the Holy Qurān has been accepted as a worship. For this reason Muslims have given great importance to teaching the Quran since the birth of Islam. This study have performed on the basis of observation and surveys about "Qur'ānTeaching Programme in 3 Days" as a Qurān teaching activity. In this direction, a survey consisting of 27 questions have applied to volunteer participants. In the study, "QurānTeaching Programme in 3 Days" was examined in terms of such variables as age, gender, educational status, socio-economic status, participants' thoughts about the program. According to the survey results and observations made during the program process, it can be said that "Qur’ānTeaching Programme in 3 Days" is a successful example of teaching Qurān.
\end{abstract}

Keywords: Teaching Qurān, Methods and Techniques in Teaching Qurān, QurānTeaching Programme in 3 Days, QurānTeaching for Adult

* $\quad$ Yrd. Doç. Dr., Marmara Üniversitesi İlahiyat Fakültesi, İDKAB Öğretim Üyesi. E-posta : umutkaya58@hotmail.com / umut.kaya@marmara.edu.tr 


\section{Giriş}

"Yaratan Rabbinin adıyla oku! O, insanı aşılanmış bir yumurtadan yarattı. Oku! İnsana bilmediklerini öğreten, kalemle (yazmayı) öğreten Rabbin, büyük bir kerem sahibidir" âyetleri ile nazil olmaya başlayan Kurân-ı Kerîm, bu âyetlerle Müslümanlara okumalarını emreder. Bu bakımdan genel olarak okuma-yazmaya ve özel olarak da Kurân-1 Kerîm’in okunmasına yönelik öğretimin Hz. Peygamber’e ilk vahyin gelmesi ile birlikte başladığ 1 söylenebilir. Müslümanlar Kurân-1 Kerîm’i yüzünden okumak, anlamını kavramak ve onunla amel etmekle mükellef olduklarından Kurân öğrenmeyi ve öğretmeyi en önemli dini vecibelerden biri olarak kabul etmişlerdir. ${ }^{1}$

Allah Teâla, bu hususta Müslümanlara Kur'ân-1 Kerîm’i anlayıp ondan ibret alsınlar diye Kur'ân-1 Kerîm’i kolaylaştırdığını bildirir. Hz. Peygamber de Kurân okuma konusunda Müslümanları teşvik etmek amaçlı birçok müjde vermiştir. Konu ile ilgili âyet ve hadislerden birkaçını burada paylaşmak yerine olacaktır.

Muhakkak Allahin kitabın okumaya devam edenler, namazı dosdoğru kilanlar, kendilerine rızık olarak verdiğimizden infak edenler, asla son bulmayan bir kazanç beklesinler. ${ }^{2}$

Andolsun ki, biz Kur'ân’ öğüt alınsın diye kolaylaştırdık. (Ondan) öğüt alan yok mu? ${ }^{3}$

Kim Allah’ın kitabından bir harf okursa, onun için bir hasene (sevap) vardır. Her hasene için ise, on misli sevap vardır. Ben "Elif, Lam, Mim" bir harftir demiyorum. "Elif" bir harf, "Lam" bir harf, "Mim" bir harftir. ${ }^{4}$

Gerçekten, sizin en hayırlınız, Kur’ân’ öğrenen ve öğretenlerinizdir. ${ }^{5}$

Tüm bu müjdeler sebebiyle İslâmiyet'in ilk yıllarından günümüze kadar Müslümanlar Kurân-1 Kerîm öğretimine ve onun okunmasına büyük önem vermişlerdir. ${ }^{6}$

Kur'ân-1 Kerîm manasıyla zihne, okunuşuyla da gönle hitap eden bir özelliğe sahiptir. Bu açıdan Kur'ân-1 Kerîm için iki türlü okunuştan bahsedilebilir. Bunlardan biri Kurân-1 Kerîm âyetlerini anlamaya yönelik zihinsel okuma yani "kıraat" olarak adlandırılır. İkinci

$196 /$ Alak: $1-5$

Mustafa Öcal, “Türkiye’de Kurân Eğitim ve Öğretiminde Görülen Gelişmeler ve Bir İcazetname Örneği”, Uludağ İlahiyat Fakültesi Dergisi, 2004, XIII, sy. 12, s. 82.

2 35/el-Fâtır: 29.

3 54/el-Kamer: 17, 22, 32, 40. Kur'ân okunmanın teşvik edildiği ve kolaylaştırıldığının bildirildiği diğer âyetler için bk. 8/el-Enfâl: 2; 44/ed-Duhân: 58; 19/Meryem: 97.

4 Ebû İsa Muhammed b. İsa b. Sevre es-Sülemî et-Tirmizî, el-Câmiu's-sahîh / Sünenü't-Tirmizî (nşs. Beşşâr Avvâd Ma'rûf), I-VI, Beyrut: Dâru'l-garbi'l-İslâmî, 1998, Fezâilü'l-Kurân, 16.

5 Muhammed b. İsmail el-Buhârî, el-Câmiu’s-sahîh (nşr. Şuayb el-Arnaût - Âdil Mürşid), I-V, Beyrut: er-Risâletü’lâlemiyye, 1432/2011, Fezâilü'l-Kurân, 21; Tirmizî, Fezâilü'l-Kur'ân, 15.

6 Kur’ân okunmasının faziletleri için bk. İsmail Karaçam, Kur'ân-ı Kerîm’in Faziletleri ve Okunma Kaideleri, İstanbul: Marmara Üniversitesi İlahiyat Fakültesi Vakfı Yayınları, 1998, s. 71-110; Ömer Halil Hasan, "Kurân-1 Kerîm Öğretimi” (trc. Yusuf Alemdar), Cumhuriyet Üniversitesi İlahiyat Fakültesi Dergisi, 2004, VIII, sy. 1, s. 263-271. 
tür okunuş ise eda, seda, tecvid, ahenk ve tavır gibi hususlara dikkat edilen ve "tilavet" olarak adlandırılan okunuştur. Kur'ân-ı Kerîm'in tilavet şeklinde okunmasında mananın ötesinde gönle ve kalbe uzanan bir etki söz konusudur. ${ }^{7}$

Anadili Arapça olan toplumlarda, Kurân-1 Kerîm okumasını öğrenmek okuma-yazma bilmekle eşdeğer olarak kabul edilebilirken, anadili Arapça olmayan ya da alfabe olarak Arap harflerini kullanmayan toplumlarda Kurân-ı Kerîm’in okunmasının öğretimi ayrı bir çaba gerektirir. Namaz gibi temel ibadetlerde Kur'ân'dan bazı bölümlerin okunması gerektiği, hatta sadece Kurân okumasının kendi başına bir ibadet olması gibi hususlar Kur'ân’n yüzünden okunmasını ve bazı bölümlerinin doğru şekilde ezberlenmesini Müslümanlar arasında önemli hale getirmiştir. Anadili Arapça olmayan ve Latin alfabesini kullanan bir ülke olarak Türkiye'de de Kurân-1 Kerîm öğretimini farklı şekilde yapmaya çalışan ve isteklilere bu konuda yardımcı olmaya çalışan birçok kurum ve kuruluş bulunmaktadır. 1925 yllından bu yana ülkemizde Kurân-1 Kerîm’in öğretilmesi faaliyeti Diyanet İșleri Başkanlığı uhdesinde faaliyetlerini sürdüren Kurân Kursları merkezli yürütülmeye çalışlmıștır. ${ }^{8}$ Kurân Kursları̉nın yanında İmam Hatip Okulları, İlahiyat Fakülteleri, Yüksek İslâm Enstitüleri de Cumhuriyet Dönemi’nde Kurân eğitim ve öğretiminin yapıldığı yerlerdir. Ayrıca son yıllarda yapılan düzenlemelerle Kurân-1 Kerîm, örgün eğitim sistemi içinde seçmeli dersler arasında yerini almıştır. Yeni düzenleme ile birlikte Kurân öğrenme imkânı daha da genişlemiştir. ${ }^{9}$

Özellikle, Diyanet İşleri Başkanlığı uhdesinde yazın ve kışın düzenlenen Kư'ân Kursları hem çocuklara hem de yetişkinlere Kurân-1 Kerîm öğrenme konusunda önemli firsatlar sunmaktadır. Örneğin Yaz Kur'ân Kursları'nda çocuklar, Kur'ân öğretimi için camilere giderek Kurân-1 Kerîm öğrenmekte, camiyi ve din görevlisini tanımaktadırlar. ${ }^{10}$ Yaz kurslarıyla ilgili yapılan bir araştırma, bu kurslara devam edenlerin daha çok ilköğretim çağındaki çocuklar olduğunu; lise çağındaki gençlerin ve yetişkinlerin ise bu kurslara yeterince ilgi göstermediğini ortaya koymaktadır. ${ }^{11}$ Yetişkinler ise daha çok kışın düzenlenen kursları tercih etmektedirler. Kursa gelmeye vakti olmayanlar ise camilerde açılan akşam kursları ile Kur'ân öğretimine devam etmektedir. ${ }^{12} 2003$ yılında yapılan yetişkinlere yönelik bir araştırmada yetişkinlerin, faaliyetlerin planlı-programlı olması, yeterli dini bilgiye, kültüre ve formasyona sahip kişiler tarafından verilmesi durumunda Kurân-1 Kerîm ve temel dini bilgilerin

7 Emin Işık, “Tarihi Gelişimi İçinde Kurân Öğretimi”, Kurân Kurslarında Eğitim, Öğretim ve Verimlilik, İstanbul: İslami İlimler Araştırma Vakfi, 2000, s. 65-66.

8 Cumhuriyet Döneminde, Kurân Kurslarının açılması ve gelişmesi süreci için bk. Zeki Salih Zengin, "Cumhuriyet Döneminde Türkiyede Kurân Kurslarının Kurulması ve Gelişmesi”, Temmuz-Aralık 2011, Çukurova Üniversitesi Illahiyat Fakültesi Dergisi, XI, sy. 2, s. 1-24.

9 Zeki Salih Zengin, “Tarihi Süreç İçerisinde Kurân Öğretimi”, Yaz Kurân Kursları Sempozyumu, Erzurum 2010, s. 9-20.

10 Ahmet Koç, "Kurân Kurslarında Din Eğitimi”, Din Eğitimi (ed. Mustafa Köylü - Nurullah Altaş), İstanbul: Ensar Neşriyat, 2014, s. 390.

11 İrfan Başkurt, Din Eğitimi Açısından Kurân Öğretimi ve Yaz Kurân Kursları, İstanbul: Değerler Eğitim Merkezi, 2007, s. 153.

12 Yaşar Kurt, “Kurân Öğretimi ve Caminin Kurân Öğretimindeki Yeri”, EKEV Akademi Dergisi, Yaz 2003, VII, sy. 16, s. 117. 
öğretilmesine yönelik Diyanet İşleri Başkanlığı uhdesinde açlacak kurslara katılım gösterecekleri ifade edilmektedir. ${ }^{13}$

$\mathrm{Bu}$ araştırmada, bir sivil toplum kuruluşu organizasyonu olarak Kurân-1 Kerîm öğretme konusunda insanların zihinlerinde Kurân-ı Kerîm’i öğrenmenin zor olduğu intibaını kırmak, onlara Kurân-1 Kerîm öğrenmenin kolay olduğunu göstermek ve Kurân-1 Kerîm öğretmek maksadıyla daha çok yetişkin ağırlıklı olmakla birlikte her yaş grubuna hitap etmeyi amaçlayan bir Kur'ân-1 Kerîm programı incelenecektir. Yaz aylarında Marmara Üniversitesi İlahiyat Fakültesi Camisi’nde "Tüm Yüksek İslâm Enstitüsü ve İlahiyat Mezunları ve Mensupları Derneği” (TIYEMDER) ve Marmara Üniversitesi İlahiyat Fakültesi ile birlikte "3 Günde Kur'ân Öğreten Program" adı ile organize edilen bu programa katılanların anket sorularına verdiği cevaplar doğrultusunda bu programda uygulanan Kurân-1 Kerîm öğretimi metotları, görevli hocaların katılımcılara karşı tutumlarının öğrenmeye etkisi, katılımcıların programdan memnuniyet düzeyleri gibi hususlar değerlendirilecektir.

\section{Araştırmanın Amacı ve Problemi}

Kur'ân Kursları, Cumhuriyet tarihi boyunca halkın genelde Kurân-1 Kerîm’i yüzünden okumayı öğrendikleri özelde ise din eğitimi öğretimi ihtiyaçlarını karşıladığı yaygın eğitim kurumlarıdır. Kurân kurslarını hizmet alanlarına göre, Yüzünden Okuma Eğitimi Verilen Kur'ân Kursları, Hafızlık Eğitimi Verilen Kur'ân Kursları ve Yaz Kur'ân Kursları olarak üç farklı kategoriye ayırmak mümkündür. Bu kurslardan, Yaz Kurân Kursları, örgün eğitim sürecinde bulunan çocukların ve gençlerin dinin temel bilgilerini öğrendikleri önemli eğitim-öğretim merkezlerinden biri olarak kabul edilir. Bu kurslar vasıtasıyla örgün eğitim süreci içinde Din Kültürü ve Ahlak Bilgisi ve seçmeli din dersleri ile birlikte temel dini bilgiler kazanan çocuk ve gençler, Kurân’ı yüzünden okumayı öğrenmekte, ibadetleri yerine getirebilmek için dua ve sureleri ezberlemekte, ibadetler hakkında temel bilgileri öğrenip toplumsal hayatın içinde uyulması gereken ahlakî prensipler hakkında bilgi sahibi olmaktadır. ${ }^{14}$ Aynı şekilde seçmeli Kurân-1 Kerîm dersini gören çocuklar da bu kurslar vasitasıyla öğrendiklerini pekiştirebilmektedirler. Bununla birlikte ülkemizde okullarda yer alan seçmeli Kur'ân-1 Kerîm dersi ve Diyanet İşleri Başkanlığı’nın organize etmiş olduğu Kurân Kurslarının yanında isteklilere Kurân-1 Kerîm okumayı öğreten gönüllü kurum ve kuruluşlar da bulunmaktadır. Bu kurumlardan biri de yaz aylarında özellikle yetişkinlere yönelik olarak "3 Günde Kurân Öğreten Program”ı Marmara Üniversitesi İlahiyat Fakültesi ile birlikte organize eden TIYEMDER'dir. ${ }^{15}$

13 Hasan Dam, "Yetişkinlere Göre Yetişkin Din Eğitimi", Değerler Eğitimi Dergisi, 2003, I, sy.4, s. 45-46.

14 http://www2.diyanet.gov.tr/EgitimHizmetleriGenelMudurlugu/KurânKursuOgretimProgrami/Yaz\%20Kurân\%20 Kurslar\%C4\%B1\%20\%C3\%96\%C4\%9Fretim\%20Program\%C4\%B1\%20-\%202005.pdf (erişim tarihi: 19.05.2017)

15

1994 yılında kurulan Tüm İlahiyat ve Yüksek İslâm Enstitüleri Mezunları Derneğìnin amacı tüzüğüne göre "illahiyat fakülteleri ve Yüksek İslâm Enstitüleri ile dengi eğitim veren fakülte ve yüksekokullardan mezun olanlar arasında kaynaşma, dayanışma ve yardımlaşmayı sağlayarak aile ve toplum bünyemizin, asli kültürümüzün, müşterek 
İlk kez 2005 yılında uygulamaya konulan bu programda 2005-2010 yılları arasında dernek verilerine göre, toplamda 7 bin 548 kişi sertifika almaya hak kazanmıştır. ${ }^{16} 2011$ yılında Marmara İlahiyat Fakültesi Camisinnin yeniden yapılmak amacıyla yıkılması ile programa bir süre ara verilmiştir. 2015 yılında Üsküdar ilçesi sınırları içinde Çilehane Camisìnde bir yll devam eden program, 2016 yılında tekrardan Marmara İlahiyat Fakültesi Camisinnde yapılmaya başlanmıştır. 2016 yılında Ramazan ayına denk gelen programa 173 kişi; 2017 yılındaki programa ise 367 kişi katılmıştır.

Tablo 1: Yillara Göre Programa Gelen Katılımcı Sayısı

\begin{tabular}{|l|l|}
\hline Yll & Katılımci Sayıs \\
\hline $\mathbf{2 0 0 5 - 2 0 1 0}$ & 7.548 \\
\hline $\mathbf{2 0 1 5}$ & Tespit Edilemedi \\
\hline $\mathbf{2 0 1 6}$ & 173 \\
\hline $\mathbf{2 0 1 7}$ & 367 \\
\hline
\end{tabular}

Program, her ne kadar yetişkinlere yönelik olarak planlanmış olsa da, gerek mekânın gerekse programın cazip gelmesinden ötürü çocuklar da velileri ile beraber bu programa katılmıştır. Bu doğrultuda çalışma grupları farklı yaş gruplarını göz önüne alarak oluşturulmuştur. Böylelikle program, anne-babaların çocukları, büyükbaba ve büyükannelerin de torunları ile beraber katıldıkları bir program haline gelmiştir. Daha önce yapılan bazı araştırmalarda Yaz Kur’ân Kursları’nda öğreticilerin en çok dile getirdiği problem alanlarından birisi olan velilerin ilgisizliği, ${ }^{17}$ bu programa katılan çocukların velileri ile birlikte programa katılmalarına imkân sağlanarak büyük oranda aşılmıştır.

Bu araştırma “3 Günde Kurân Öğreten Program”ının akışı hakkında bilgi verip yukarıda belirtilen konularda veri toplamak ve bunları değerlendirmek suretiyle yaz aylarında daha çok yetişkinlere yönelik yapılan "3 Günde Kurân Öğreten Program”n değerlendirilmesini amaçlamaktadır. Bu araştırmanın temel konusu/problemi ise farklı bir tecrübe ve metotla uygulanan “3 Günde Kurân Öğreten Program”"dır. Bu bağlamda araştırma çerçevesinde aşağıdaki sorulara alt problemler olarak yanıt aranmıştır:

ulvi değerlerimizin, tabiat ve çevremizin, tarih ve kültür mirasımızın, öz estetiğimizin korunması ve geliştirilip yaygınlaştırılması, aileler ve sosyal gruplar arasında kültür ve ahlakı, sevgi ve işbirliğini, birlik ve beraberliği arttırıcı faaliyetlerde bulunarak hürriyet ve bekamızın teminine hizmet etmek"tir.

16 http://www.dunyabulteni.net/servisler/haberYazdir/123567/haber (erişim tarihi: 11.04.2015); TIYEMDER Dernek Verileri.

17 Ahmet Koç, "Yaz Kurân Kursları Üzerine Bir Araştırma”, Diyanet İlmi Dergi, 2011, XLVII, sy.2, s. 19-20; Ahmet Koç, "Kur'ân Kurslarında Eğitim ve Verimlilik", Etkili Din Öğretimi (ed. Şaban Karaköse), İstanbul: Türkiye İlahiyat Tedrisatına Yardım Eden Dernekler Federasyonu, 2010, s. 499-514; Mehmet Korkmaz, "Öğretici Görüşlerine Göre Yaz Kurân Kurslarının Sorunları (Kayseri Örneği)”, Bilimname, 2011, XXI, sy. 2, s. 143-144. 
a) "3 Günde Kurân Öğreten Program"a katılanlar sosyo-ekonomik, yaş ve cinsiyet olarak nasıl bir profil oluşturmaktadırlar? b) Programa katılanların programdan ve programda görev yapan hocalar hakkındaki memnuniyet oranları nedir? c) Programa katılanların, programa gelmeden önceki ve program bitimindeki Kur'ân-1 Kerîm okuma seviyeleri arasında değişiklik var mıdır?

\section{Araştırmanın Sınırlılıkları ve Yöntemi}

Araştırma verileri ve değerlendirmeler, 2016 yılında anketin uygulandığı Marmara İlahiyat Fakültesi Camisi’nde, “3 Günde Kur’ân Öğreten Program”ına katılanlarla sinırlıdır.

Araştırmada, tarama tipi araştırma modeli kullanılmıştır. Tarama tipi araştırmalar, araştırmaya konu edilen grubun cinsiyet, yaş, medeni hali, gelir düzeyi, öğrenim durumu gibi araştırmaya konu özelliklerini belirlemek amacıyla yapılan betimsel araştırmalardır. Bu tür araştırmalarda uygun bir ölçme aracı kullanılarak bu veriler üzerinde frekans, ortalama gibi işlemler yapılarak sonuçlara ulaşılır. ${ }^{18}$

Araştırmada veri toplama aracı olarak anket kullanılmakla beraber, gözlem tekniği ve Kurân-1 Kerîm öğretimi ile ilgili olarak daha önce yapılmış çalışmalardan da ilgili literatür taranmak suretiyle yararlanılmıştır. Aynı șekilde araştırmada, 2007 yılında yapılan ancak yayınlanmayan bir anket çalışmasının verileri de karşılaştırma amacıyla kullanılarak tarihsel yönteme de başvurulmuştur.

\section{Veri Toplama Aracı ve Verilerin Çözümlenmesi}

Araştırmada veri toplamak için, programa katılan katılımcılara yönelik bir anket uygulamasına yer verilmiştir. Programın uygulanış biçimine ilişkin veriler ise yazarın kendi gözlemleri ve program uygulayıcısı uzman hoca ile yapılan görüşme sonucunda elde edilmiştir. ${ }^{19}$

Ankette kullanılan çoktan seçmeli sorularla elde edilen nicel veriler SPSS İstatistik Programında çözümlenmiş ve değerlendirilmiştir. Araştırmaya katılanların, yaşı, cinsiyeti, medeni durumu, öğrenim durumu, mesleği, sosyo-ekonomik düzeyi ile ilgili frekans/yüzdelik tabloları çıkartılarak programa katılanların profili ortaya konulmaya çalışılmıştır. Aynı şekilde, ankette yer alan programa katılmadan önceki ve katıldıktan sonraki Kurân-1 Kerîm okuma bilgisi, programa katılma sebebi, verilen ödevlere zaman ayırıp ayıramamas1, programda görev yapan hocalar ile ilgili görüşleri frekans/yüzdelik değerleri ile tablo şeklinde verilmiștir.

Abdullah Can, SPSS ile Bilimsel Araştırma Sürecinde Nicel Veri Analizi, Ankara: Pegem Akademi, 2016, s. 8-9.

TIYYEMDER ve Marmara İlahiyat Fakültesi adına programı yürüten Ferruh Erel, Diyanet İşleri Başkanlığı’nda imam hatip olarak görev yapmaktadır. 
$\mathrm{Bu}$ araştırmada kullanılan anket, daha önce bu programla ilgili veri toplamak üzere 2007 yılında Veysel Uysal tarafından uygulanan ancak yayınlanmayan anket çalışmasının gözden geçirilmesi ile oluşturulmuştur. Aynı şekilde söz konusu anket çalışmasının verileri de yer yer 2016 yılı ile kıyaslama amacıyla kullanılmıştır. ${ }^{20}$

2007 yılında uygulanan anket gözden geçirilip ön uygulamaya tabi tutulduktan sonra son şekli verilen anket formu, katılımcılara uygulanmış ve katılımcıların cevaplarını herhangi bir etki altında kalmadan verilebilmesi için gerekli ortamın sağlanmasına azami titizlik gösterilmiştir. Uygulama yapılmadan önce katılımcılara araştırmanın amacı ile ilgili gerekli açıklamalar yapılmış, yönlendirdikleri soruların yanıtlandırılmasının akabinde anket uygulamasına başlanılmıştır. Uygulanan anket formunda sorulan 27 soru iki kısımda gruplandırılmıştır. Kişisel bilgiler adıverilen ilk bölümde ankete katılanlara yaşı, cinsiyeti, medeni durumu, öğrenim durumu, mesleği ve sosyo-ekonomik düzeyi ile ilgili olmak üzere 6 soru sorulmuştur. Anketin ikinci kısmındaki sorular ise "3 Günde Kurân Öğreten Program”1 ile ilgilidir. Bu bölümde katılımc1lara programla ilgili 21 soru sorulmuştur. Katılımcılara yöneltilen sorular neticesinde elde edilen veriler SPSS Bilgisayar İstatistik Paket Programında çözümlenmiş, frekans ve yüzdelik dağılımı tablolarda gösterilmiştir. Bunun yanında katılımcılara anket sonunda program hakkındaki görüş ve önerilerinin neler olduğuna dair açık uçlu bir soru da yöneltilmiş ve program hakkındaki görüşlerinin alınması hedeflenmiştir. Ancak katılımcıların bu kısma verdikleri cevaplar değerlendirildiğinde, bu kısmın programın gelişmesine katkı verecek türden cevaplar ihtiva etmesi beklenirken, ankete katılanlarının program düzenleyicilerine ve hocalarına teşekkür ettikleri bir bölüm halini aldığı görülmüştür. Son olarak program, ilana çıkış tarihiyle beraber başlayan kayıt alma işlemlerinden programın sona erip sertifikaların törenle katılımcılara verildiği son güne kadar yaklaşı bir ay boyunca izleyici olarak gözlemlenmiştir. Bu gözlem sonucunda elde edilen veriler de araştırmanın içinde değerlendirilerek verilmiştir.

\section{Araştırma Grubu}

Araştırma, 2016 yılında Marmara İlahiyat Fakültesi Camisi altında yapılan "3 Günde Kur’ân Öğreten Program”'nda ${ }^{21}$ uygulanan anketle gerçekleştirilmiştir. Anket, bu programa devam eden ve araştırma grubunu oluşturan 173 katılımcı içerisinden tesadüfi olarak 111 katılımcıdan veri toplanmak suretiyle uygulanmıştır. Araştırma grubunu oluşturan katılımcıların cinsiyet, yaş, medeni durum, meslek ve sosyo-ekonomik düzey değişkenlerine göre dağılımı şöyledir:

202007 yılına ait veriler, Veysel Uysal tarafından yapılan ancak yayınlanmayan anket sonuçlarına göre elde edilen verilerdir. Söz konusu veriler Veysel Uysal'dan alınmıștır.

21 “3 Günde Kur'ân Öğreten Program”ından bundan sonra "Program” şeklinde bahsedilecektir. 


\subsection{Araştırma Grubunun Yaşlarına Göre Dağılımları}

Tablo 2: Araştırma grubunun yaşlarına göre dağılımı ${ }^{22}$

\begin{tabular}{|l|c|c|}
\hline Yaş & Sayı & \% \\
\hline $\mathbf{7 - 1 0}$ & 2 & 1,8 \\
\hline $\mathbf{1 1 - 1 4}$ & 10 & 9,0 \\
\hline $\mathbf{1 5 - 2 0}$ & 5 & 4,5 \\
\hline $\mathbf{2 1 - 3 9}$ & 15 & 13,5 \\
\hline $\mathbf{4 0 - 5 9}$ & 57 & 51,3 \\
\hline $\mathbf{6 0}$ ve üzeri & 22 & 19,6 \\
\hline Toplam & $\mathbf{1 1 1}$ & $\mathbf{1 0 0}$ \\
\hline
\end{tabular}

Programa katılanlar yaş, cinsiyet, medeni durum, öğrenim durumu, meslek ve sosyo-ekonomik açıdan değerlendirildiğinde, ilk göze çarpan programa katılanların yaşlarıdır. Aynı şekilde elde edilen verilere göre programa katılanların yaş ortalaması 44, en çok tekrar eden yaş ise (mod) 46'dır. Programa katılım yaşının (ranj aralığı) 7'den 84’e kadar geniş yelpazede olduğu görülmektedir.

Program, yaz aylarında uygulanmasına rağmen katılımcıların yarısından fazlasının yani \%51,3’ünün orta yetişkinlik olarak nitelendirilebilecek bir yaş grubu içerisinde olduğunu söylemek mümkündür. Bu yaş grubunu \%19,6 ile yaşlılık dönemi olarak adlandırabileceğimiz 60 ve üstü yaş grubunun izlemesi bu programın daha çok 40 yaş ve üstü yetişkinlere cazip geldiğini göstermektedir. Bununla birlikte programa ilk yetişkinlik dönemi yaş aralı̆̆ında (21-39) bulunan kimselerin gelme oranı \%13,5, 20 yaş altı katılımcıların oranı ise \%15,3’tür. Özellikle 20 yaş altı grubu katılımcıların ise programa daha çok anne-baba, büyükbaba ya da büyükanneleri ile birlikte geldikleri gözlemlenmiştir.

Programın ilk uygulandığı yıllardan 2007'de yapılan programda uygulanan anket sonuçlarına bakıldığında da, programa devam eden kursiyerlerin daha çok yetişkin bireyler oldukları görülmektedir. 2007 yılında programa gelenler arasında 15 yaş altı oran \% 17,9 olmuştur. Aynı ankette programa 45 yaş ve üstü katılımcıların oranı da \%38,1 olmuştur. Aynı şekilde 2010 yılında yayınlanan bir başka çalışmada, 2010 yılındaki programa katılanların \%20’sinin çocuk, \%80'inin ise yetişkin olduğu ifade edilmektedir. ${ }^{23}$ Bu çalışmada elde edilen veriler de bu durumu teyit etmektedir. On yıl içinde üç farklı zaman içinde yapılan anket sonuçları, programın daha çok yetişkinlere hitap ettiğini göstermektedir.

22 Ankette yer alan yaşla ilgili veriler, okuyucunun verileri daha kolay takip edebilmesi için gelişimsel basamaklara göre sınıflandırılarak tablo halinde verilmiştir. Buna göre, 6/7-10 yaşları son çocukluk dönemi, 11-14 yaşları ilk ergenlik dönemi, 15-20 yaşları son ergenlik dönemi, 21-39 yaşları yetişkinlik dönemi, 40-59 yaşları orta yaş dönemi, 60 ve üstü yaşlar ise yaşlılık dönemi olarak değerlendirilmiştir.

23 Mehmet Faruk Bayraktar, "Yaz Kurân Kurslarında Yapılan Eğitim-Öğretim Üzerine Düşünceler”, Yaz Kur'ân Kursları Sempozyumu (09-11 Temmuz 2010), Erzurum: Tortum Müftülüğü, ts, s. 34. 


\subsection{Araştırma Grubunun Cinsiyetlerine Göre Dağılımları}

Tablo 3: Araştırma grubunun cinsiyete göre dağılımı

\begin{tabular}{|l|l|l|}
\hline Cinsiyet & Sayı & $\%$ \\
\hline Kadın & 58 & 52,3 \\
\hline Erkek & 53 & 47,7 \\
\hline Toplam & 111 & $\mathbf{1 0 0}$ \\
\hline
\end{tabular}

Katılımcıların cinsiyetlerine göre dağılımlarına bakıldığında, kadınların erkeklere kıyasla programa biraz daha fazla rağbet ettikleri söylenebilir. Buna göre kadınların programa katılım oranı \%52,3 iken erkeklerin oranı \%47,7'dir. Cinsiyet değişkeninin yaşa göre farklılaşmasına baktığımızda, programa en çok rağbet gösteren yaş grubu olan 40 yaş üstünde kadınların erkeklere oranla daha fazla katılım gösterdikleri görülmektedir. Buna göre 40 yaş üstü katılımcılarda kadınların oranı \%54,5 erkeklerin oranı ise \%45,5’tir.

2007'deki anket verilerine bakıldığında ise kadınların 2016'ya göre katılım oranlarının daha yüksek olduğu görülmektedir. 2007 yılında programa katılan kadınların oranı \%63,1; erkeklerin oranı ise \%36,9'dur. 2007 ve 2016 yılındaki verilere göre erkek-kadın oranı yorumlanırsa, son programda erkek-kadın oranı açısından daha dengeli bir dağılım görüldüğü söylenebilir.

\subsection{Araştırma Grubunun Medeni Durumlarına Göre Dağılımları}

Tablo 4: Araştırma grubunun medeni durumlarına göre dağılımı

\begin{tabular}{|l|l|l|}
\hline Medeni Durum & Sayı & $\%$ \\
\hline Evli & 67 & 60,4 \\
\hline Bekâr & 32 & 28,8 \\
\hline Dul (Eşi vefat etmiş) & 7 & 6,3 \\
\hline Boşanmış & 5 & 4,5 \\
\hline Toplam & $\mathbf{1 1 1}$ & $\mathbf{1 0 0}$ \\
\hline
\end{tabular}

Katılımcıların medeni durumlarını gösteren tabloya bakıldığında, programa katılanların büyük çoğunluğunun $(\% 60,4)$ evli olduğu görülür. Bu açıdan programın daha çok hayatın içerisinde bazı şeyleri gerçekleştirmesine rağmen, dinî açıdan yaşamlarında bir eksiklik (Kurân-1 Kerîm okuyamamak gibi) hissedip bu eksiklerini telafi etmek için gelenlerin tercih ettiği ifade edilebilir. 


\subsection{Araştırma Grubunun Öğrenim Durumlarına Göre Dă̆ılımları}

Tablo 5: Araştırma grubunun öğrenim durumlarına göre dağılımı

\begin{tabular}{|l|l|l|}
\hline Öğrenim Durumu & Say1 & $\%$ \\
\hline Okur-yazar & 7 & 6,3 \\
\hline İlköğretim & 28 & 25,2 \\
\hline Ortaokul / Lise & 35 & 31,5 \\
\hline Lisans & 35 & 31,5 \\
\hline Yüksek Lisans / Doktora & 6 & 5,4 \\
\hline Toplam & $\mathbf{1 1 1}$ & $\mathbf{1 0 0}$ \\
\hline
\end{tabular}

Katılımcıların öğrenim durumlarına bakıldığında, lisans ve lisansüstü eğitim görenlerin oranının \%36,9 ile en yüksek seviyede olduğu görülmektedir. Bu rakamı \%31,5 ile lise ve \%25,2 ile ilköğretim izlemektedir. Özellikle bu oran programa en çok katılan 40 yaş üstü grupta oldukça göze çarpmaktadır. 40 yaş üstünde lisans/lisansüstü eğitim gören 35 kişi vardır. Tabloya göre ilköğretim düzeyinden lisansüstü eğitim alanlara kadar geniş bir kesim programı tercih etmektedir. Bu tablo aynı zamanda, katılımcıların gruplara ayrılması aşamasında bu farklıkların göz önüne alınmasının da gerekli olduğunu göstermektedir.

Öğrenim durumlarını 2007 yılında programa gelenlerle kıyaslamak gerekirse, 2007 yılında programa katılanların \%6,2'sinin okur-yazar, \%26,4'ünün ilkokul, \%16,3'ünün ortaokul, \%27,5'inin lise, \%23,6'sının ise üniversite mezunu olduğu görülmektedir. Yukarıda yer alan tablo ile kıyaslandığında okur-yazar ve ilköğretim mezunlarının oranlarının hemen hemen aynı olduğu görülür. Öte yandan 2007 yılında programa katılanların en yoğun olduğu mezuniyet derecesi ortaokul/lise iken (\%43,8), 2016 yılında programa katılanlar arasında en yüksek oranı $(\% 36,9)$ lisans ve lisansüstü mezuniyet derecesidir.

\subsection{Araștırma Grubunun Mesleklerine Göre Dağılımları}

Tablo 6: Araştırma grubunun mesleklerine göre dağılımı

\begin{tabular}{|c|c|c|c|c|c|c|c|c|c|}
\hline Meslek & $\sum^{\Xi}$ & 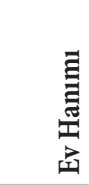 & 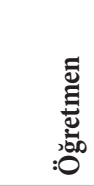 & 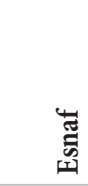 & 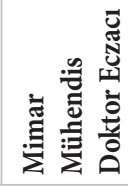 & 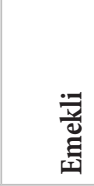 & $\begin{array}{l}\overline{\mathscr{U}} \\
: \vec{U} \\
: 0\end{array}$ & 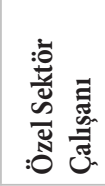 & Toplam \\
\hline Sayı & 1 & 23 & 8 & 6 & 7 & 22 & 15 & 29 & 111 \\
\hline$\%$ & 0,9 & 20,7 & 7,2 & 5,4 & 6,3 & 19,8 & 13,5 & 26,1 & 100 \\
\hline
\end{tabular}

Katılımcıların mesleki durumlarına bakıldığında, en yüksek üç oranı özel sektör çalışanları $(\% 26,1)$, ev hanımları $(20,7)$ ve emeklilerin $(19,8)$ oluşturduğu görülmektedir. Bu orana 
\%13,5 oranında öğrenciler de eklendiğinde katılımcıların büyük çoğunluğunun yaz aylarında vakitlerinin müsait olduğu ya da Kurân-1 Kerîm öğrenimi için vakit ayırabilecek esnek çalışma saatlerine sahip oldukları söylenebilir. Bu programın yapıldı̆̆ı zaman dilimi 2016 yılında Ramazan ayına denk geldiğinden, program önceki senelerden farklı olarak tek seans şeklinde uygulanmıştır. Daha önceki senelerde gün içinde üç farklı zaman diliminde sabah/öğle/ikindi olmak üzere üç farklı seansta gün boyu eğitim verilmekteydi. Bu durumun gelen katılımcı sayısını önceki senelere göre düşürdüğünü söylemek mümkündür. Bununla beraber, Kurân-1 Kerîm eğitimi için isteklilere esnek saatler sunulduğunda, Kurân-1 Kerîm okumayı öğrenmek isteyen birçok kimsenin günlük planlarını buna göre ayarlayıp Kurân-1 Kerîm öğrenmek için vakit ayırdığı söylenebilir.

2007 yılındaki programın katılımcı profiline bakıldığında da meslek gruplarına göre benzer dağılımların olduğu görülmektedir. 2016 yılında programa katılanların yarısı ev hanımı, emekli ve öğrencilerden oluşurken, 2007 yılındaki programda da bu oran benzerlik gösterir. 2007 yılındaki programa katılan ev hanımı, öğrenci ve emeklilerin toplam oranı $\% 55,5$ 'tir.

\subsection{Araştırma Grubunun Sosyo-Ekonomik Durumlarına Göre Dağılımları}

Tablo 7: Araştırma grubunun sosyo-ekonomik durumlarına göre dağılımı

\begin{tabular}{|l|l|l|}
\hline Sosyo-ekonomik durum & Sayı & $\%$ \\
\hline $\mathbf{1 4 0 0}$ TL & 7 & 6,3 \\
\hline $\mathbf{1 4 0 1}-\mathbf{2 0 0 0}$ TL & 21 & 18,9 \\
\hline $\mathbf{2 0 0 1}-\mathbf{2 7 5 0}$ TL & 18 & 16,2 \\
\hline $\mathbf{2 7 5 1}-\mathbf{4 0 0 0}$ TL & 30 & 27,0 \\
\hline $\mathbf{4 0 0 1}$ TL ve üstü & 27 & 24,3 \\
\hline Cevapsiz & 8 & 7,2 \\
\hline Toplam & $\mathbf{1 1 1}$ & $\mathbf{1 0 0}$ \\
\hline
\end{tabular}

Katılımcıların sosyo-ekonomik durumlarına bakıldığında \%24,3 oranında bir kesimin gelir seviyelerinin 4001 TL ve üstünde olduğu görülür. Katılımcıların \%7,2’si ise bu soruyu cevapsız bırakmıştır. 2750 TL ve üstü ekonomik kazanca sahip olanların oranı ise \%41,3’tür. $\mathrm{Bu}$ açıdan programa katılanların çoğunluğunun ekonomik açıdan orta gelir düzeyi ve üstünde (2751 TL ve üstü) olduğu söylenebilir. Bu oran, katılımcıların öğrenim durumlarının seviyesi ile de benzerlik gösterir. Bu açıdan bakıldığında, programa katılanların büyük çoğunluğunun hem ekonomik durum hem de öğretim seviyesi bakımından toplumun genel seviyesinin üstünde olduğu söylenebilir. 


\section{5. “3 Günde Kur’ân Öğreten Program”}

Bu başlık altında "3 Günde Kurân Öğreten Program"ın işleyiş süreci hakkında bilgi verilip programa katılanlara yapılan anket sonuçları tablolarla gösterilip değerlendirilecektir. Kurân-1 Kerîm okumayı öğrenmenin basit olduğu düşüncesiyle yola çıkılan ve bu motivasyonla faaliyet gösteren programın ana hedefi, görsel ve teknolojik imkânlardan faydalanarak, koro ile sık sık tekrarlar yapmak suretiyle, Elif-Bầy mümkün olduğunca basitleştirip hoca-talebe arasındaki birebir ilişkiyi verimli bir şekilde kullanarak başta yetişkinler olmak üzere, genç ve çocukların kafalarındaki Kur'ân-ı Kerîm’i okumak zordur algısını yıkarak, yaz aylarında kısa süre zarfında Kurân-1 Kerîm okumayı öğretmektir. Bu program, geleneksel ve modern eğitim-öğretim tekniklerini birleștiren bir eğitim-öğretim faaliyetidir. ${ }^{24}$

İsteyen herkesin herhangi bir kota uygulanmaksızın katılabildiği iki aşamadan oluşan programda öncelikle katılımcılara konferans salonunda projeksiyon ile sunum yapılarak harfler, harekeler, bazı basit tecvit kuralları öğretilmekte ve her harfin bir nesnenin resmiyle eşleştirilerek ezberlenmesi sağlanır, daha sonra harflerin birleştirilerek kullanımı öğretilir. Harflerin öğretilmesinde harfin ismi değil sesi esas alınır. Örneğin “ " ğil bu harfin sesi olan "şş̧" sesi öğretilir. Bu sayede katılımcılar harflerin ismi ile çıkarmış olduğu sesleri okuyuş esnasında karıştırmamaktadır.

Programda yüzünden Kur'ân-1 Kerîm okuma çalışmaları bol tekrarlı koro çalışması şeklinde yapılmaktadır. Normal Elif-Bâ cüzü yerine basitleştirilmiş bir Elif-Bâ kullanılan bu programın ikinci aşamasında ise geleneksel usulle katılımcılar, 10-15’er kişilik grup ile halka şeklinde hoca-talebe ilişkisi içerisinde öğrenimlerine devam etmektedirler. Bu çalışma metodunda, 1,5 saat konferans eğitimi; 1,5 saat bire bir hoca-talebe dersi olmak üzere, 3 günde toplam 9 saat süren bir eğitimden sonra katılımcılar Kurân okumaya başlamaktadırlar. Katılımcıların akşam evlerinde yaptıkları tekrarlar da başarıyı arttıran önemli bir etken olarak durmaktadır. 2016 yılında katılımcıların beyanatlarına göre, katılımcıların günün sonunda evde Kur'ân-1 Kerîm’e vakit ayırma oranları \%90 civarında çıkmıştır.

Programın günlük çalışmasının ilk bölümü konferans salonunda yapılır. Burada katılımcılar, uzman hoca rehberliğinde görsel hafıza teknikleri ile öğrendiklerini ezberlemekte ve koro halinde bolca tekrar yapmaktadırlar. Günlük çalışmanın ikinci bölümünü oluşturan grup çalışmasında ise yaş, cinsiyet ve bireysel öğrenim farklılıkları gözetilmek suretiyle bir gruplandırma yapılarak çalışma halkaları oluşturulmaktadır. Halkalar her grup hocasına 10-15 civarında katılımcı düşecek şekilde düzenlenir. Bu şekilde daha önce yapılan araştırmalarda özellikle Yaz Kurân Kursu öğreticilerinin Kurân Kursları ile ilgili sorun/olumsuzluk olarak zikrettikleri yaş ve sınıf farklılıklarının ${ }^{25}$ önüne geçilmesi hedeflenmiştir. Bu

24 Daha sonraki yıllarda farklı illerde yetişkinlere yönelik farklı program denemeleri olmuștur. Örneğin Van’da uygulanan bir program hakkında bk. Şaban Karasakal, "Yetişkinlere Kısa Sürede Kurân Öğretimi, Uygulama Yöntem ve Teknikleri”, Yecder II. Din Görevlileri Sempozyumu Cami Merkezli Din Eğitimi (haz. Şadettin Göksu), İstanbul: Sarıgazi Yunus Emre Camii Külliyesi Eğitim ve Kültür Derneği, 2011, s. 113-131.

Korkmaz, "Öğretici Görüşlerine Göre Yaz Kurân Kurslarının Sorunları”, s. 138. 
farklılıkların dikkate alındığı böyle bir düzenlemenin programın verimliliğine olumlu yönde bir katkı yaptığı söylenebilir.

Programda grup çalışmalarında dikkat edilen hususlardan biri de, hocalar ile katılımcıların uyum içinde çalışabilecekleri bir ortam oluşturulmasıdır. Zira hoca ile talebe arasında var olan uyum, başarıyı olumlu yönde etkilemektedir. Bu husus Kurân-1 Kerîm öğretiminde daha büyük önem kazanmaktadır. Çünkü talebe, hoca ile yaşamış olduğu anlaşmazlığı ya da uyumsuzluğu ders ile özdeşleştirebilmekte ve dersten/Kurân-1 Kerîm okumaktan soğuyabilmektedir.

Kurân-1 Kerîm öğretiminde hocanın önemi, Kurân öğretiminde mutlaka taklit edilmesi gereken bir örneğe ihtiyaç duyulmasından da kaynaklanmaktadır. Kurân’ın doğru okunabilmesi için tespit edilen esaslar (tecvîd) konusunda bilgi sahibi olmak veya bu konu ile ilgili bütün kaideleri ezberlemek yeterli olamamaktadır. Tecvîd kaidelerini bilmek işin sadece teorik yönünü oluşturur. Pratik tarafı ise bu esasların belirlenen şekilde icra edilmesi yani uygulanmasıdır. Bu yüzden Kur'ân’n öğretimi tıpkı pratik yönü ağırlıklı olan resim, müzik vb. sanat dalları gibi hocaya ihtiyacı zorunlu kılmaktadır. Bu nedenle Kurân öğretimi dini ilimler arasında hocaya en çok ihtiyaç duyulan ilim olarak kabul edilir. ${ }^{26} \mathrm{Bu}$ husus, genel tecvid kaidelerinin uygulanmasının yanında, okunması özellik arz eden yerlerin telaffuzu, temsil kaidelerine riayet etmek gibi Kurân okuyuşunun incelikleri, Kur'ân harflerinin çıkarılmaları ve yerli yerinde okunması bakımından daha çok zorunluluk arz etmektedir. ${ }^{27} 2016$ yılında gözlemlenen program sürecinde program düzenleyicilerinin bu hususun farkında olarak, katılımcılar ile hocaları arasındaki uyuma önem gösterdiklerini belirtmek yerinde olacaktır.

Katılımcıların Kurân okumaya geçtikten sonra bu defa sırasıyla, namaz sûrelerini ve Yasin suresini yüzüne okumaları daha sonra ise ilk hatimlerine de hocaların denetiminde başlamaları hedeflenmektedir. Böylece katılımcıların hem öğrendiklerini pekiştirmiş olması hem de hatasız ve daha düzenli bir şekilde Kurân’’ hoca gözetiminde okuma imkânını elde etmiş olması amaçlanmaktadır.

"3 Günde Kurân Öğreten Program” hakkında belirtilmesi gereken en önemli hususlardan birisi programın bir ay sürmesidir. Program, üç günün sonunda Kurân-1 Kerîm’e geçmeyi hedeflediği için bu isimle ön plana çımaktadır. Buna göre, katılımcıların Kurân-1 Kerîm’e geçtikten sonra öğrendiklerini pekiştirmeleri ve hatime başlamaları için program bir ay sürecince devam etmektedir. Bir katılımcı çeşitli nedenlerden dolayı üçüncü günün sonunda Kur'ân-1 Kerîm’e geçemezse, Kurân-1 Kerîm’e geçtiği günden itibaren hatim çalışmasına başlayabilmektedir.

Bu doğrultuda programın beş günlük zaman dilimi içindeki akışı şöyledir: ${ }^{28}$

İsmail Karaçam, "Kur'ân Öğretim Metodunun Ana Çizgileri", Din Öğretimi ve Din Hizmetleri Semineri (8-10 Nisan 1988), Ankara: Diyanet İşleri Başkanlığı Yayınları, 1991, s. 121. 
Daha önce yukarıda zikredildiği üzere dersler konferans ve ders halkası şeklinde iki bölüm halinde yapılmaktadır. İlk bölüm konferans salonunda, ikinci bölüm ise caminin içinde halka halindeki grup çalışması şeklinde icra edilir.

İlk gün birinci derste; ilk olarak katılımcılara program boyunca motivasyonlarını üst düzeyde tutacak, Kur'ân-1 Kerîm öğrenmenin zor bir şey olmadığı inancını kuvvetlendirecek daha önceden yaşanmış tecrübelerin de aktarıldığı bir moral konuşması ile programa başlanır. Daha sonra harflerin projeksiyon cihazı yardımıyla görüntüleri yansıtılmakta ve koro halinde tekrar uygulaması yapılır. ${ }^{29} \mathrm{Bu}$ aşamada, her harf bir fotoğrafla eşleştirilerek katılımcılara gösterilir. Bu işlem ders boyunca defalarca tekrar eder. Sonra harf ve fotoğraflar karışık olarak verilerek katılımcıların öğrenme seviyeleri görülür.

İlk günün ikinci dersinde ise; daha önceden yaş ve cinsiyete göre ayrılmış gruplarla katılımcıların hocalarıyla bire bir çalışması sağlanmaktadır. Her on-on beş katılımcının bir hoca ile çalıştığı bu bölümde hem konferans salonunda öğrenilenler tekrarlanmakta hem de katılımcıların öğrenip öğrenemedikleri kontrol edilir. Bu aşama, bir buçuk saat sürer. Yapılan derslerin ise evde tekrarı tavsiye edilir. Bu aşama aynı zamanda Kurân-1 Kerîm öğretim metotlarından sema-arz metodunun yoğun olarak uygulandığı bir bölümdür. Sema, öğrencinin görebileceği bir yerde hocanın bulunduğu, mümkünse öğrencilerin bir halka şeklinde oturup hocayı dinlediği ve gözlemlediği bir öğretim metodudur. Kurân-1 Kerîm öğretiminde öğrencinin hocasına okumasını ifade eden arz metodunda ise hoca öğrencisini dikkatle dinler, varsa hatalarını söyler, düzeltmesi için fırsat verir, düzeltmediği durumlarda ise kendisi örnek olarak tekrar okur. ${ }^{30}$

İkinci gün birinci derste; birinci günün hızlı bir tekrarından sonra harekeler öğretilir. Bu konu da görüntülü ve koro halinde tekrarlarla işlenir. Dersin sonuna doğru, katılımcılara harflerin birbirine nasıl katılacağı konusunda kısa bir çalışma yaptırılmaktadır. İkinci günün ikinci dersinde; ilk günün konuları kısaca tekrar edildikten sonra harekeli harflerin okutulması aşamasına geçilir. Dersin sonunda basit örneklerle harflerin birbirine katılması gösterilir. Daha sonra ise "kısa ve kolay sözcükleri okuma" aşamasına geçilir. Bu konuda dikkat çekici noktalardan birisi de örnek olarak okutulan kelimelerin Kurân-1 Kerîm’de sıklıkla geçmesine özen gösterilmesidir. Bu bölümde hoca önce okur, ardından ise katılımcılardan doğru bir şekilde tekrarlaması istenir. Bu yöntemi genel eğitim-öğretim yöntemleri açısından gösterip-yaptırma yöntemi olarak adlandırmak mümkündür. Gösterip yaptırma yöntemi, din öğretiminde

29 Kurân-1 Kerîm öğretiminde koro çalıșması Kurân öğretiminde talebeleri aktif hale getiren, talebelerin defalarca tekrar yapmasını sağlayan bir yöntemdir. Bu yöntem, talebenin üzerindeki heyecanı azaltmakta ve güven kazandırmaktadır. Koro çalışması öğrenciye kısa zamanda çok tekrar imkânı vermekte ve öğretilenlerin kısa sürede muhatabın zihnine yerleşmesini sağlamaktadır (bk. Fatih Çollak, "Kurân-1 Kerîm Öğretim Teknikleri", Etkili Din Öğretimi (ed. Şaban Karaköse), İstanbul: Türkiye İlahiyat Tedrisatına Yardım Eden Dernekler Federasyonu, 2010, s. 517).

30 Necati Tetik, "Kurân Tilavetinin veya Kıraat İlminin Öğretilmesi Usulleri”, Atatürk Üniversitesi İlahiyat Fakültesi Dergisi, 1990, sy. 9, s. 239-243; Nazif Yılmaz, Kurân-ı Kerîm’i Nasıl Öğretelim, İstanbul: Değerler Eğitim Merkezi, 2016, s. 52-53. 
abdest, namaz gibi bazı ibadet konularının öğretiminde kullanılabildiği gibi, Kurân-1 Kerîm öğretiminde harflerin doğru telaffuzunda, tecvit kaidelerinin öğretilmesinde, Kurân-1 Kerîm’i makamına uygun okuma becerilerinin kazandırılmasında kullanılabilir.

Üçüncü gün birinci derste; birinci ve ikinci günlerin konularının hızlı bir tekrarından sonra projeksiyona besmele, kelime-i şehadet, İhlas ve Fatiha sûreleri gibi bilinen okuma parçaları yansıtılarak bu parçaların okunmasına geçilir. Bu parçalar koro halinde katılımcılara tekrar ettirilir. Böylece akılda kolay kalabilecek kelime gruplarının tekrar edilmesiyle harekelerin okunuşu ve harflerin birbirine katılması pekiştirilir. Üçüncü günün ikinci dersinde; aynı çalışma bu kez de hocalar ile beraber yapılır. Bu aşamada katılımcılara söz konusu kelime öbekleri ve sureler bire bir uygulama ile okutulmaktadır. Bu okuma daha sonra koro halinde tekrarlatılarak pekiştirilmektedir. Bu aşamada katılımcılara Kurân üzerinde küçük uygulamalar da yaptırılmış olduğundan Kurân-1 Kerîm’i okuyabileceklerine dair motivasyon da sağlanmaktadır.

Programın dördüncü gününde ise, Kurân okumaya geçilir. Dördüncü günün ilk dersinde; tecvidin ana konularından medd ile ilgili bilgi verilir. Bu kısımda tecvîd ile ilgili inceliklere girilmez. Daha sonra Fatiha ve Elif-Lam-Mim ile Yasin sûreleri okunup hatme başlamak hedeflenir. Dördüncü günün ikinci dersinde; Fatiha Suresi ve Bakara sûresinin ilk beş âyeti üzerinde meddlerin uygulaması yaptırılır.

Beşinci güne gelindiğinde ise, her iki ders boyunca okunan parçaların sıkça tekrar yapılarak öğrenilenlerin pekiştirilmesi hedeflenir. Bu aşamadan itibaren katılımcıların vakti müsait ise, hatme başlaması, değil ise en azından amme cüzünü okuması amaçlanır. Bir ay sonunda programı başarı ile bitiren katılımcılara ise başarı sertifikası verilip Kurân-ı Kerîm hediye edilmektedir.

Tablo 8: Programın beş günlük akışı

\begin{tabular}{|c|c|c|c|}
\hline Gün & ers & Yer & Yapilanlar \\
\hline \multirow{2}{*}{ 1. Gün } & 1. Ders & Konferans Salonu & $\begin{array}{l}\text { Kurân-1 Kerîm okumasını öğrenmenin fazileti hakkında motive edici konuşma } \\
\text { Harflerin fotoğraflarla eşleştirilerek öğretilmesi }\end{array}$ \\
\hline & 2. Ders & Cami & $\begin{array}{l}\text { 10-15 kişilik gruplara ayrılma } \\
\text { Harflerin öğrenilmesi ve pekiştirme çalışmaları }\end{array}$ \\
\hline \multirow{2}{*}{ 2. Gün } & 1. Ders & lonu & Harekeler ve harflerin birleştiril \\
\hline & 2. Ders & Cami & Harekeli harflerin okunması, k1 \\
\hline \multirow[t]{2}{*}{ 3. Gün } & 1. Ders & Konferans Salonu & $\begin{array}{l}\text { adet, İhlas ve Fatiha sûrelerinin koro ile } \\
\text { ciş) }\end{array}$ \\
\hline & 2. Ders & ; & ele, İhlas ve Fatiha Surelerinin okunması \\
\hline \multirow[t]{2}{*}{ 4. Gün } & 1. Ders & Konferans Salonu & $\begin{array}{l}\text { Med kurallarının öğretilmesi, Fatiha, Bakara Suresi ilk beş âyetinin okunma } \\
\text { alıstırmaları }\end{array}$ \\
\hline & 2. Ders & Cami & Fatiha ve Bakara sûresi ilk beş âyeti üzerinde medlerin uygulanması \\
\hline \multirow{2}{*}{ 5. Gün } & 1. Ders & Konferans Salonu & \multirow{2}{*}{$\begin{array}{l}\text { Her iki ders boyunca Yasin sûresi ya da Amme cüzündeki sûreler üzerinden } \\
\text { birinci ders koro ile ikinci ders ise bireysel olarak alıstırma yapmak }\end{array}$} \\
\hline & 2. Ders & Cami & \\
\hline
\end{tabular}


Programa katılanlar, takribi olarak üç günün sonunda Kurân-1 Kerîm’e geçerek okuma çalışmalarına başlamaktadır. 3 gün gibi kısa bir sürede Kur'ân-1 Kerîm ile çalışmak, hiç şüphesiz özellikle seneler içinde zihinlerinde "Kur’ân-1 Kerîm okumayı öğrenmenin zor bir şey olduğu algısını oluşturan" katılımcılar açısından bir motivasyon kaynağı olmaktadır. Hatta bazı katılımcılar, "3 günde Kurân-1 Kerîm öğretilemez” ön yargısı ile programa katıldıklarını ancak üç gün sonunda bu ön yargılarının yıkıldığını; bir ay sonunda ise Kur'ân-1 Kerîm’i rahatlıkla kendi başlarına okuyabilecek derecede öğrendiklerini ifade etmektedirler.

Bu programın katılımcılar açısından önemli bir özelliği de esnek kurs saatleri olmaktadır. Çalışanların, ev hanımlarının, çocukların durumu ve yoğun katılım gözetilerek program gün içinde iki hatta üç kez tekrar edilmektedir. Hatta sadece hafta sonları müsait olan kursiyerlere ise, hafta sonlarında daha yoğun bir program takip edilerek, birebir eğitimle hafta içi gelmedikleri günler telafi edilmeye çalışılmaktadır.

Program uygulayıcıları tarafından bu programın ana hedefinin hem Kur'ân’ çok kolay öğretmek hem de Kur'ân’n çok kolay öğrenildiği psikolojisini yaymak olduğu ifade edilir. Hoca başına düşen talebe sayısının azaltılması ve teknolojik imkânların doğru tekniklerle birleştirilmesi sonucunda başarıya ulaşmayı hedefleyen bu programla, katılımcılardan bazılarının edindiği öğrenilmiş çaresizliğin de önüne geçilmiş olunmaktadır. "İlkokuldayken yaz aylarında Kur'ân Kursu'na giderdim. 3 ay boyunca Elif Be’yi okur tam Kurân-1 Kerîm’e geçmişken okullar açılırdı. Maalesef öğrendiklerimi kendi başıma tekrar edemediğimden, öğrendiklerimi seneye kadar unutur ve sonraki yaza yeniden Elif Bèden başlardım”, şeklindeki bir katılımcının ifadesi maalesef bu konuda sıkça duyulabilecek olan örneklerden birisidir. Her yıl yaz kurslarında bir hocaya çok sayıda talebe düşmesi vb. sıkıntılardan ötürü kursa gidenlerin Kur'ân’ tam öğrenemeden ayrılması, çocukluktan itibaren Kurân-1 Kerîm okunması öğrenilemez bir kitap psikolojisi oluşturmaktadır. Son yıllarda Diyanet İşleri Başkanlığı’nın bu konu üzerine eğilerek Yaz Kurân Kursları için bir program geliştirmesi ve materyaller hazırlanması vb. gelişmeler, olumlu gelişmeler olarak sayılabilir.

“3 Günde Kurân Öğreten Program”ın katılımcılar açısından diğer farklı bir yönü, toplumun her kesiminden, her yaş grubundan insanın hatta zaman zaman üç farklı neslin birlikte Kurân öğrenmek için bir araya gelmesidir. Programa, gelini ve torunuyla birlikte katılan kayınvalidelerin bunun en güzel örneğini oluşturduğu söylenebilir. Bu süreçte katılımcıların Kurân okumaya geçtiklerindeki sevinçleri ise gerçekten görülmeye değerdir. Program hakkında basına yansıyan haberlere göre daha önce çocukken camide Kurân eğitimi aldığını belirten 38 yaşındaki bir katılımcı, Kurân-1 Kerîm’i yllarca tekrar etmeyerek unuttuğunu; kendi başına kitaplardan okuyarak öğrenmeye çalıştığını ancak bir yerden sonra tıkandığını aktarmaktadır. Söz konusu katılımcı programda verilen eğitimin farklı olduğunu, semboller sayesinde bir günde bütün harfleri ezberleyip, ikinci günde hecelemeye ve okumaya başladığını ifade etmektedir. ${ }^{31}$ 


\section{Bulgular ve Yorumlar}

Bu başlık altında “3 Günde Kurân Öğreten Program”ına katılan katılımcıların program hakkındaki görüşleri incelenecektir.

\subsection{Araştırma Grubunu Programa Katılış Amaçları}

Tablo 9: “3 Günde Kur’ân Öğreten Program”ına Katılış Amaçları

\begin{tabular}{|l|l|l|}
\hline Programa katılıs amaçları & Sayı & $\%$ \\
\hline Kurần-1 Kerîm okumayı öğrenme isteği & 97 & 87,4 \\
\hline Duyurunun çarpıcıllğı & 2 & 1,8 \\
\hline Seminerin yapılacağı mekânın güzelliği & 1 & 0,9 \\
\hline Ramazan ayında sevap işleme güdüsü & 3 & 2,7 \\
\hline Kurân-1 Kerîm okumayı geliştirme isteği & 8 & 7,2 \\
\hline Toplam & $\mathbf{1 1 1}$ & $\mathbf{1 0 0}$ \\
\hline
\end{tabular}

Tablo 9'dan izlenebileceği gibi araştırmaya katılanlar büyük bir oranda programa katılma amaçlarının Kur’ân-1 Kerîm’i okumayı öğrenmek $(\% 87,4)$ olduğunu ifade etmişlerdir. Programa katılanların \%7,2'si ise Kur'ân okumayı bildiklerini ancak Kur'ân okumalarını ilerletmek için geldiklerini belirtmişlerdir. Ankette bu iki şıkkı işaretleyenlerin toplam oranına baktığımızda (\%94,6), programa katılanların çoğunluğunun programın ismine, programın yapıldığı mekâna çok fazla bakmaksızın doğrudan Kur’ân okumayı öğrenmek ve okumalarını geliştirmek amacıyla katıldıkları söylenebilir. 2007 yılında yapılan programda uygulanan anket sonuçlarında da benzer sonuçlar çıkmıştır. 2007 yılında programa katılanlar da yüksek bir oranda (\% 92,8) Kur’ân okumayı öğrenme isteği amacıyla programa katıldıklarını ifade etmişlerdir.

\subsection{Araştırma Grubunun Programa Katılmadan Önceki Kur’ân-1 Kerîm Okuma Seviyesi}

Tablo 10: Programa katılmadan önceki Kur'ân-1 Kerîm okuma bilgisi

\begin{tabular}{|l|l|l|}
\hline Programa katıldıktan önceki Kur’ân-1 Kerîm okuma seviyesi & Sayı & $\%$ \\
\hline Kurân-1 Kerîm okumayı hiç bilmiyordum & 49 & 44,1 \\
\hline Harfleri tanıyordum & 27 & 24,3 \\
\hline Okununca takip edebiliyor, ancak kendi başıma okuyamıordum. & 10 & 9,0 \\
\hline Tecvîdsiz de olsa kendi kendime okuyabiliyordum. & 25 & 22,5 \\
\hline Toplam & 111 & 100,0 \\
\hline
\end{tabular}


Tablo 10'da görüldüğg̈ gibi, programa katılanların büyük bir çoğunluğu Kurân-1 Kerîm

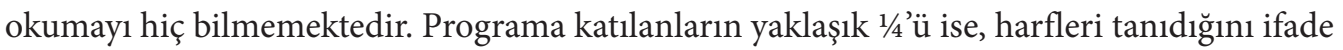
etmektedir. Programa katılanların yaklaşık 1/3’ü ise Kurân-1 Kerîm’i okununca takip edebildiğini ya da kendi kendine tecvîdsiz de olsa okuyabildiğini belirtmektedir. Buna göre programa katılanların yüzde \% 68,4'ünün Kurân-1 Kerîm okumayı hiç bilmediğini söylemek mümkündür. Programa katılanlar arasında Kurân-1 Kerîm’i okumayı az da olsa bilenlerin oranının ise yaklaşık $1 / 3$ olduğu daha önce ifade edilmişti. Grup çalışması aşamasında, gruplar oluşturulurken bu seviye farkı dikkate alınarak gruplar oluşturulmaktadır.

\subsection{Araştırma Grubunun Programa Katıldıktan Sonraki Kur'ân-1 Kerîm Okuma Seviyesi}

Tablo 11: Programa katılmadan sonraki Kurân-1 Kerîm okuma seviyesi

\begin{tabular}{|l|l|l|}
\hline Programa katıldıktan sonraki Kur'ân-1 Kerîm okuma seviyesi & Sayı & $\%$ \\
\hline Sadece harfleri tanıyorum. & 6 & 5,4 \\
\hline Okununca takip edebiliyor, ancak kendi başıma okuyamıyorum. & 18 & 16,2 \\
\hline Tecvidsiz de olsa kendi kendime okuyabiliyorum. & 74 & 66,7 \\
\hline Tecvidli okumaya başladım. & 13 & 11,7 \\
\hline Toplam & 111 & 100,0 \\
\hline
\end{tabular}

Tablo 12: Programın Kurân-1 Kerîm okuma bilgi ve beceri düzeyine katkısı

\begin{tabular}{|l|l|l|}
\hline Programın Kur'ân-1 Kerîm okuma bilgi ve beceri düzeyine katkısı & Sayı & $\%$ \\
\hline Çok arttırdı & 67 & 60,4 \\
\hline Oldukça arttırdı & 36 & 32,4 \\
\hline Biraz arttırdı & 8 & 7,2 \\
\hline Hiçbir değişim olmadı. & 0 & 0 \\
\hline Toplam & 111 & 100,0 \\
\hline
\end{tabular}

Ankete cevap veren katılımcıların cevaplarına göre, tablo 11 ve 12'de görüldügü üzere, katılımcıların Kurân-1 Kerîm okuma seviyelerinde bir iyileşme olduğu görülür. Katılımcıların tablo 12'de yer alan "Programın Kurân-1 Kerîm okuma bilgi ve beceri düzeyine katkısı" hakkında sorulan soruya verilen cevaplar arasında "Hiçbir değişim olmadı" cevabını seçenlerin olmayışından programın katılımcıların Kurân-1 Kerîm okuma seviyelerine olumlu yönde katkı yaptığı sonucu çıkartılabilir. Aynı şekilde katılımcıların "Programa katılmadan önce ve katıldıktan sonraki Kurân-1 Kerîm okuma seviyesi” hakkındaki sorulara verdikleri cevaplar müstakil olarak incelendiğinde, katılımcılardan sadece 13 kişinin programın önce ve sonrasında tecvîdsiz de olsa kendi kendime okuyabiliyorum şeklinde aynı cevabı verdikleri görülür. Bunun haricindeki diğer tüm katılımcıların cevaplarına bakıldığında, en az bir üst seviye Kurân-1 Kerîm okuma bilgisine işaret eden cevaplar verdikleri görülmektedir. 
Tablo 11'de gösterilen verilere göre, program sonunda Kur'ân-1 Kerîm okumaya geçenlerin oranının \%78,4; sadece harfleri tanıma seviyesinde kalanların oranının ise \%5,4 olması, programın Kurân-1 Kerîm okuma yönünden verimli bir program olduğunu göstermektedir.

Tablo 12'deki verilere bakıldığında ise, ankete katılan katılımcıların çoğuna göre $(\% 92,8)$ programın Kurân-1 Kerîm okuma bilgi ve becerilerine katkısı yüksek düzeyde olmuştur. 2007 yılında yapılan programda uygulanan ankette de katılımcılara aynı soru sorulmuştur. 2007 yılındaki katılımcılar da \%91,0 gibi yüksek bir oranda programın Kurân-1 Kerîm okuma bilgi ve becerilerine katkısının yüksek düzeyde olduğunu ifade etmişlerdir.

\subsection{Araştırma Grubunun Seminerlere Katılım ve Ödevlere Zaman Ayırabilme Durumları}

Tablo 13: Katılımciların programa devam durumu

\begin{tabular}{|l|l|l|}
\hline Programa düzenli devam durumunuz nasıldı? & Sayı & $\mathbf{\%}$ \\
\hline Her gün devam etmeye çalıştım & 44 & 39,6 \\
\hline Haftada 3-4 gün gelmeye çalıștım & 48 & 43,2 \\
\hline Haftada 2-3 gün gelmeye çalıștım & 15 & 13,5 \\
\hline Ara sıra uğradım & 4 & 3,6 \\
\hline Toplam & $\mathbf{1 1 1}$ & $\mathbf{1 0 0 , 0}$ \\
\hline
\end{tabular}

Tablo 14: Katılımcıların okuma ödevlerini yerine getirme durumu

\begin{tabular}{|l|l|l|}
\hline Okuma ödevlerini yerine getirebildiniz mi? & Sayı & $\mathbf{\%}$ \\
\hline Evet getirdim & 50 & 45,0 \\
\hline Kısmen getirdim & 52 & 46,8 \\
\hline Pek getiremedim & 6 & 5,4 \\
\hline Hiç getiremedim & 3 & 2,7 \\
\hline Toplam & $\mathbf{1 1 1}$ & $\mathbf{1 0 0 , 0}$ \\
\hline
\end{tabular}

Tablo 13, katılımcıların büyük çoğunluğunun programa yoğun bir şekilde devam ettiklerini göstermektedir. Tablo 13’e göre, katılımciların \%91,8'inin devam konusunda gayretli olduğunu söylemek mümkündür. Katılımcıların "Okuma ödevlerini yerine getirebildiniz mi?” şeklindeki soruya verdikleri cevaplara göre, katılımcıların büyük çoğunluğunun $(\% 91,8)$ programda öğrendiklerini evlerinde tekrar etmeye çalıştıkları söylenebilir. Programda Kurân’a kısa sürede geçme başarısında, katılımcıların hem programa devam durumlarının hem de verilen okuma ödevlerini büyük ölçüde yerine getirmelerinin olumlu yönde bir etkisi olduğunu söylemek mümkündür. 


\subsection{Araştırma Grubunun Program Hakkındaki Görüşleri}

$\mathrm{Bu}$ başlık altında katılımcılara programdan memnuniyetleri ve beklentileri ile ilgili görüşleri sorulmuş, alınan cevaplara göre tablolar şu şekilde oluşturulmuştur:

Tablo 15: Araştırma grubunun programdan memnuniyet düzeyleri ve beklentilerini karşılama oranı

\begin{tabular}{|l|l|l|l|l|}
\hline & \multicolumn{2}{|l|}{$\begin{array}{l}\text { Programa katılmaktan ne } \\
\text { derece memnunsunuz? }\end{array}$} & \multicolumn{2}{l|}{$\begin{array}{l}\text { Program beklentilerinizi ne ölçüde } \\
\text { karşıladı? }\end{array}$} \\
\hline & Sayı & $\%$ & Sayı & $\%$ \\
\hline Çok memnunum / Tamamen karşıladı & 90 & 81,1 & 61 & 55,0 \\
\hline Oldukça memnunum / Oldukça karşıladı & 21 & 18,9 & 49 & 44,1 \\
\hline Fikrim yok & 0 & 0 & 0 & 0 \\
\hline Pek memnun değilim / Pek karşılamadı & 0 & 0 & 1 & 0,9 \\
\hline Hiç memnun değilim / Hiç karşımadıa & 0 & 0 & 0 & 0 \\
\hline Toplam & $\mathbf{1 1 1}$ & $\mathbf{1 0 0 , 0}$ & $\mathbf{1 1 1}$ & $\mathbf{1 0 0 , 0}$ \\
\hline
\end{tabular}

Tablo 16: Araştırma grubunun programın tekrar düzenlenmesi hakkındaki görüşleri

\begin{tabular}{|l|l|l|}
\hline Böyle bir programın düzenlenmesi ile ilgili görüşleriniz nelerdir? & Sayı & $\%$ \\
\hline Diğer bölge ve semtlerde de düzenlenmeli & 52 & 46,8 \\
\hline Sürekli düzenlenmesi faydalı olur & 16 & 14,4 \\
\hline Her sene muhakkak düzenlenmeli & 43 & 38,7 \\
\hline Bir kere verilmesi yeterli, yeniden düzenlenmese de olur. & 0 & 0 \\
\hline Toplam & $\mathbf{1 1 1}$ & $\mathbf{1 0 0 , 0}$ \\
\hline
\end{tabular}

Katılımcılar program hakkında kendilerine yöneltilen sorulara çoğunlukla olumlu cevaplar vermişlerdir. Programa katılmaktan memnuniyet dereceleri ve programın beklentilerini karşılama ölçüsü ile ilgili soruları katılımcıların büyük çoğunluğu programa katılmaktan memnuniyet duyduğu ve programın beklentilerini karşıladığı yönünde yanıtlamışlardır. Katılımcılardan sadece biri programın beklentilerini pek karşılayamadığını ifade etmiştir. Bu haliyle programın katılımcılar tarafından değerlendirilmesinin oldukça olumlu ve memnuniyet oranının oldukça yüksek olduğunu belirtmek gerekir. Programın tekrar düzenlenmesi ile ilgili soruya ise, katılımcıların hepsi yeniden düzenlenmesi yönünde görüş belirtmişlerdir. Katılımcıların \%46,8'si bu programın farklı bölgelerde de uygulanmasını, \%53,2'si ise her sene sürekli olarak uygulanması gerektiğini ifade etmişlerdir.

\subsection{Araştırma Grubunun Programda Görev Yapan Hocalarla İlgili Görüşleri}

Bu başlık altında ise katılımcıların hocalarla ilgili görüşlerine yer verilmiştir. Katılımcıların programda günün ilk dersini konferans şeklinde yapan uzman hoca ve grup çalışmalarında görev alan hocalarla ilgili görüşleri aşağıdaki tablolarda görüldüğü gibi olmuştur. 
Tablo 17: Toplu olarak yapılan seminerdeki hocanın konuya hâkimiyeti

\begin{tabular}{|l|l|l|}
\hline Toplu olarak yapılan konferanstaki hocanın konuya hâkimiyeti sizce nasıldı? & Sayı & \multicolumn{1}{|c|}{$\%$} \\
\hline Çok iyi & 89 & 80,2 \\
\hline Yeterli & 18 & 16,2 \\
\hline Fikrim yok & 0 & 0 \\
\hline Daha iyi olabilir & 4 & 3,6 \\
\hline Yetersiz & 0 & 0 \\
\hline Toplam & $\mathbf{1 1 1}$ & $\mathbf{1 0 0 , 0}$ \\
\hline
\end{tabular}

Tablo 18: Grup hocasının Kur'ân-1 Kerîm okumayı öğrenmeye katkısı

\begin{tabular}{|l|l|l|}
\hline Grup hocanızın Kur'ân-1 Kerîm öğrenmenize katkısı nasıldı? & Sayı & $\mathbf{\%}$ \\
\hline Çok iyi (\%100) & 89 & 80,2 \\
\hline Oldukça iyi (\%75) & 17 & 15,3 \\
\hline Orta (\%50) & 3 & 2,7 \\
\hline Zayıf (\%25) & 2 & 1,8 \\
\hline Hiç & 0 & 0 \\
\hline Toplam & $\mathbf{1 1 1}$ & $\mathbf{1 0 0 , 0}$ \\
\hline
\end{tabular}

Tablo 19: Grup hocasının size karşı tutumu

\begin{tabular}{|l|l|l|l|l|l|l|}
\hline $\begin{array}{l}\text { Grup hocanızın size karşı tutumunu nasıl } \\
\text { değerlendirirsiniz? }\end{array}$ & $\begin{array}{l}\text { Ç o k } \\
\text { iyi }\end{array}$ & İyi & Orta & Zayıf & $\begin{array}{l}\text { Ç o k } \\
\text { Zayıf }\end{array}$ & Ortalama \\
\hline İlgili & 97 & 9 & 5 & 0 & 0 & 4,82 \\
\hline Saygılı & 104 & 2 & 5 & 0 & 0 & 4,89 \\
\hline Cana yakın & 102 & 4 & 5 & 0 & 0 & 4,87 \\
\hline Yardımcı & 100 & 6 & 5 & 0 & 0 & 4,85 \\
\hline Anlayışlı & 102 & 4 & 5 & 0 & 0 & 4,87 \\
\hline Teşvik edici & 100 & 4 & 7 & 0 & 0 & 4,83 \\
\hline Adaletli & 101 & 3 & 6 & 1 & 0 & 4,83 \\
\hline Genel Ortalama (5 Tam puan üzerinden) & & & & & 4,85 \\
\hline
\end{tabular}

Gerek yetişkin eğitimi gerekse çocuk eğitimi açısından öğretici ile öğrenen arasındaki iletişimin kuvvet derecesi, başarıyı önemli ölçüde etkileyen faktörlerin başında gelir. Özellikle yetişkin eğitiminde başarı oranları, yetişkinlerin faaliyetlere devam etmeleri ile öğreticinin kendilerine karşı takınmış olduğu tutum ve tavırla yakından ilişkilidir. Yetişkinlere gösterilen ilgi, saygı, sevgi, anlayış, yardımcı olma, onları başarıya teşvik etmek ve cesaretlendirmek onların başarısını olumlu yönde etkilemektedir. ${ }^{32}$

32 Yetişkinlerin Kur'ân Kurslarındaki din eğitimi için daha geniş bilgi için bk. M. Akif Kılavuz, "Kurân Kursları ve Yetişkin Din Eğitimi”, Etkili Din Öğretimi (ed. Şaban Karaköse), İstanbul: Türkiye İlahiyat Tedrisatına Yardım Eden Dernekler Federasyonu, 2010, s. 157-158. 
Bir dersin sevilmesi ve benimsenmesinin, öğrenci ve öğreten arasındaki iletişim düzeyi ile doğrudan ilgili olduğu söylenebilir. Bu iletişim düzeyi, konu Kurân-1 Kerîm olduğunda daha çok önem kazanır. Zira Kurân, sadece bir ders kitabı değil, aynı zamanda İslâm Dini’nin kutsal kitabıdır. Öğretim sürecinde öğrencinin, öğreticisi üzerinde edindiği olumlu-olumsuz düşünceler, direkt olarak Kurân-1 Kerîm okunmasının sevme-sevilme düzeyini de etkilemektedir. Gerçekten öğrencinin dersi sevmesi, Kurân-1 Kerîm’i sevmesi, onu okumayı sevmesi manasına gelir. Bu süreçte yaşanabilecek bir olumsuzluk, kişinin hayatı boyunca eline Kurân almak istememesine neden olabilir, zira Kur'ân-1 Kerîm’i her eline aldığında hocasının kendisine karşı olumsuz tutum ve davranışlarını hatırladığı için huzursuzluk yaşayabilir. ${ }^{33}$

1992 yılında Kurân Kursları ile ilgili yapılan bir alan araştırmasında, öğrencileri kurslarda en çok üzen durumların başında (\%82 oranında) öğretmenlerinin sergilemiş olduğu adaletsiz tavırlar, öğrenciler ile alay edilmesi ve öğretmenleri tarafından azarlanmaları, arkadaşlarının yanında ceza verilmesi gibi durumların geldiğini gördügümüzde, ${ }^{34}$ tablo 1718-19’da gördügümüz öğretici tavrı ile ilgili olumlu sonuçlar, aradan geçen yıllar boyunca Kurân-1 Kerîm öğretiminde bu alandaki eksikliklerin giderildiğini göstermesi bakımından önem arz etmektedir.

Yukarıda yer alan tablolara baktığımızda, katılımcıların büyük çoğunluğunun $(\% 96,4)$ programın ilk bölümünde konferans salonunda dersi veren uzman hocanın konuya hâkimiyetini yeterli ve çok iyi olarak değerlendirdikleri görülür. Bu tablo, ilgili hocanın katılımcılar üzerinde olumlu bir etki bıraktığı, bu etkinin de öğrenmeye olumlu yansıdığı şeklinde yorumlanabilir.

Katılımcıların programın günlük çalışmaların ikinci bölümünde beraber grup çalışması yaptıkları hocalarla ilgili görüşleri de benzer çıkmıştır. Katılımcıların \%95,7'si grup hocalarını Kurân öğrenmelerine katkısı bakımından oldukça iyi ve çok iyi şeklinde değerlendirmişlerdir. Aynı şekilde katılımcılara grup hocalarının kendilerine karşı takınmış oldukları tavırlarla ilgili (ilgili, saygıll, cana yakın, yardımcı, teşvik edici, adaletli) sorulara ise, ortalama 5 üzerinden 4,85 puan verdikleri görülür. Katılımcıların bu sorulardan en yüksek puanı verdikleri tavır 4,89 puan ile hocalarının kendilerine karşı "saygılı olması" tavrı; en düşük puan verdikleri ise 4,82 puan ile "ilgili olma" tavrıdır.

Söz konusu üç tablo birlikte değerlendirildiğinde, katılımcıların yüksek bir oranda hocalarından memnun oldukları, hocalarının kendilerinin Kurân-1 Kerîm okumasına katkı sağladıklarını düşündükleri sonucu çıkmaktadır. Program bitiminde yapılan gözlemlerde de, katılımcıların hocalarına veda ederken duygusal anlar yaşamaları, hocalarına hediyeler almaları da tablolarda görülen bu olumlu ilişkiyi destekler mahiyettedir. Burada görülen olumlu tablonun, programın başarısındaki önemli faktörlerden birisi olduğu söylenebilir. 


\section{Sonuç ve Öneriler}

Kurân-1 Kerîm öğrenimi ve öğretimi Müslümanların en önem verdiği hususlardan birisidir. Ülkemizde bu amaçla, gönüllü vatandaşların öğrenebilmesi için Diyanet İşleri Başkanlığı tarafından Kur'ân Kursları açılmakta, okullarda seçmeli olarak Kurân-1 Kerîm dersleri okutulmaktadır. Bunun yanında bazı sivil toplum kuruluşları da düzenledikleri faaliyetler ile gönüllü olanlara Kurân-1 Kerîm öğretmeyi amaçlamaktadırlar. Bu araştırmanın konusu olan "3 Günde Kur’ân Öğreten Program”ı da bu manada sivil toplum kuruluşları tarafından organize edilen Kur'ân-1 Kerîm öğretimi faaliyetlerine örnek olarak gösterilebilir.

Programın genel olarak başarılı olmakla birlikte yapılan gözlemlere dayanılarak geliştirilmesi gereken yanları olan bir Kur’ân öğretim modeli olduğunu söylemek mümkündür. Araştırmanın alt problem/soru başlıklarını oluşturan hususlara göz attığımızda, programın esasen daha küçük yaşlarda Kurân-1 Kerîm öğrenme firsatı bulamamış yetişkinlere yönelik olarak tasarlanmış bir program olsa da, programa her yaş grubundan bireylerin katıldı̆̆ı görülmektedir. Aynı şekilde katılımcıların cinsiyetlere göre dağılımlarında da bir denge vardır. Programa gelenlerin genel olarak eğitim seviyelerinin lise ve üstü olmasını, katılımcıların küçüklüklerinde bir şekilde Kurân okumayı öğrenme firsatı bulamasalar da kendilerine uygun imkânlar sağlandığında Kurân okumayı öğrenmek istedikleri şeklinde yorumlamak mümkündür.

Programa katılanların Kurân-ı Kerîm okuma seviyelerine bakıldığında, katılımcıların yaklaşık \%70’inin Kur’ân-ı Kerîm okumayı bilmediğini, \%30’un ise okumalarını geliştirmek için geldiği söylenebilir. Program sonundaki Kurân-1 Kerîm okuma seviyelerine bakıldığında ise, yaklaşık \%80 oranında Kur’ân okuyabildikleri, \%15 oranındaki katılımcıların ise Kur'ân'ı okununca takip edebildiklerini ifade ettikleri görülür. Bu oranlara bakıldığında program başında \%30 civarında olan Kur'ân okumayı bilme seviyesinin \%95’e çıktığı görülmektedir. Bu verilerin, programın Kurân öğretimi konusunda başarılı bir model olduğunu gösterdiğini söylemek mümkündür.

Programa katılanların programda görev alan hocalar ile iletişimlerine bakıldığında hem anket sonuçlarına göre hem de programda yapılan gözlemlere göre, programda görev alan hocalarla katılımcılar arasında iyi bir iletişim olduğu, bunun da programın başarısına olumlu yönde katkı sağladığı söylenebilir. Öğrencinin dersi öğretmeni ile özdeşleştirdiği düşünülürse, program sürecince gerçekleşen olumlu iletişim ortamının başarıya olumlu yönde etki etmektedir.

Ülkemizde Kur'ân-ı Kerîm öğretiminde farklı yöntem ve teknikler kullanılagelmektedir. Bu konuda ortak bir yöntem ve teknikten bahsetmek pek mümkün değildir. Her öğretici, belli ilke ve esaslar çerçevesinde kendince faydalı olduğuna inandığı ve/veya faydasını gördüğü yöntem ve tekniği uygulayagelmektedir. Programda kullanılan yöntem ve tekniklere bakıldığında farklı zekâ türlerine hitap eden yöntem ve tekniklerin kullanıldığ 
görülmektedir. Programda teknolojik imkânlardan da faydalanılarak harflerin fotoğraflarla gösterimi, koro ile tekrar, grup çalışması ve gösterip yaptırma gibi katılımcıların sürece dâhil olduğu, öğrencilerin bireysel farklılıklarını dikkate alan, farklı zeka alanlarına hitap eden yöntem ve tekniklere başvurulduğu söylenebilir.

Kurân-1 Kerîm öğretiminde başarıyı etkileyen en önemli faktörlerden birisi de hoca başına düşen öğrenci sayısıdır. Hoca başına düşen öğrenci sayısı arttıkça hocanın öğrencileri ile bire bir ilgilenme şansı azalmakta, bu durum da başarıyı olumsuz şekilde etkilemektedir. Bu durum Kurân-1 Kerîm öğretiminde karşılaşılması en muhtemel sorunlardan birisidir. "3 Günde Kurân Öğreten Program”nda ise bu hususa dikkat edildiği görülmektedir. Cinsiyet, öğretim durumu, Kurân-1 Kerîm okuma seviyesi gibi temel kriterler esas alınarak oluşturulan gruplarda hoca başına düşen talebe sayısının 15'i geçmemesine dikkat edildiği gözlemlenmiştir. Hoca-talebe sayısındaki bu dengenin de başarıyı olumlu yönde etkilediğini söylemek mümkündür. Katılımcıların yaş, öğretim durumu, cinsiyet, meslek ve sosyo-ekonomik durumları ile Kurân öğrenmeleri konusunda bir farklılık olup olmadığına bakıldığında ise, anlamlı bir fark olmadığı görülmüştür.

Kurân-1 Kerîm öğretimi sıklıkla tekrar etmeyi gerektiren bir eğitim-öğretim sürecidir. "3 Günde Kur'ân Öğreten Program"da katılımcllardan da vakitleri ölçüsünde kendilerine evde tekrar etmeleri için bazı ödevler ve alıştırmalar verilir. Katılımcıların da anket cevaplarından anlaşıldığı kadarı ile büyük oranda evde bu alıştırmalara zaman ayırdıkları görülür. Program boyunca katılımcılardan evde Kur'ân-1 Kerîm'den belirli bir miktar parçayı tekrar etmeleri istenir. Kur'ân öğretiminde çok sayfa okumak yerine, az miktarda bir kısmı çok miktarda okumanın hızı arttırdığı göz önüne alındığında, verilen ev ödevlerinin başarıyı arttırdığı ifade edilebilir.

Yetişkinlere yönelik bir proje olarak yola çıkılmasına rağmen belli oranda çocukların da rağbet ettiği " 3 Günde Kurân Öğreten Program” türü programların sayısının artması, çeşitli sebeplerle Kur'ân-1 Kerîm öğrenememiş bireylerin Kurân öğrenmesine imkân vermesi aç1sindan önem arz etmektedir. Bu tür programlarda esas olan Kurân-1 Kerîm’e hangi gün geçileceği değildir. Önemli olan yapılan planlama sonunda en kısa sürede Kurầna geçilmesidir. Bu sürenin üç gün, beş gün, yedi gün ya da on gün olması önemli değildir. Programdan elde edilen veriler göstermektedir ki, yaz aylarında çocuklara yönelik Yaz Kurân Kursları’nın yanında en azından merkezi bölgelerde yetişkinlere yönelik de Kurân çalışmaları yapılması ebeveynlere de çocukları ile beraber kurslara katılma imkânını verecektir.

Bununla birlikte programın geliştirilmeye açık taraflarının olduğunu şahsî gözlemlere dayanarak söylemek mümkündür. Programın geliştirilmesi gereken yanları da geliştirildiğinde programın daha verimli bir hale geleceği ifade edilebilir. Öncelikle program tanıtım afişlerinde programın ismiyle alakalı olarak programın üç gün değil, bir ay süren bir program olduğunun belirtilmesi gerekir. Programa başvuran çoğu kimse, programın üç gün sürdüğünü zannetmekte programın bir ay sürdügünü ise ilk günkü tanıtım toplantısında 
öğrenmektedirler. Bu doğrultuda programın bir ay süren bir zaman zarfında gerçekleştiği duyurularda etkin olarak yer almalıdır. Aynı şekilde, program isminin marka haline gelecek kadar basında yer almasına karşın, Kurân-1 Kerîm’e geçiş süresi boyunca kullanılan programa özel bir Elif-Bảnın ya da Kur’ân’a geçiş rehberinin olmaması da eksiklik olarak nitelendirilebilecek unsurlardan birisi olarak göze çarpmaktadır. Program düzenleyicilerinin programı geliştirmesi gereken noktalardan birisi de teknoloji ile alakalıdır. Çünkü programın ilk kısmı projeksiyon eşliğinde görsellerle desteklenerek yapılmaktadır. Ülkemizde bütün camilerde bu imkânın olmadığı göz önüne alındığında bu hususun da geliştirilmesi gerektiği söylenebilir. Bu şekilde teknolojik imkânı olmayan mekânlar için ise, görsel desteği sağlayabilmek için büyük boy posterler bastırılması faydalı olacaktır. Benzer şekilde, programın en dikkat çekici taraflarından birisi de hoca-talebe oranıdır. Programın başarısındaki en büyük etkenlerden bir tanesi budur. Ancak her camide projeksiyon cihazı vb. teknolojik imkanlar bulunmadığı gibi, ülkemizin her şehrinde bu kadar öğreticiyi bulmak ve organize etmek kolay görünmemektedir. Programın en etkili yönlerinden birisi olan hoca sayısının fazla olması hususu, bu programı düzenlemek isteyenlerin önünde aşılması gereken bir engel gibi durmaktadır. Ancak bu problem, etkili bir organizasyon ile gönüllü ilahiyat fakültesi ve imam-hatip lisesi öğrencileri ile çözülemeyecek bir problem olarak durmamaktadır.

Ayrıca bu tür programlarda ilahiyat fakülteleri ile işbirliğine gidilmesi toplumun temel dini bilgileri doğru kaynaklardan öğrenebilmesi ve toplumun ilahiyat fakültesi öğretim üyelerine daha kolay ulaşabilmelerine imkân sağlaması açısından önemlidir. Yapılan araştırmada programın daha önce düzenlendiği yıllarda ilahiyat hocaları tarafından katılımcılara bilgilendirici seminerler verildiği görülmüştür. Hz. Peygamber'in hayatı, bazı surelerin tefsiri, İslâm esasları, sünnetin hayata yansıması gibi konulara yer verilen bu seminerlerin katılımcıların talepleri doğrultusunda yeniden düzenlenmesinin, katılımcıların kafalarında dinle ilgili oluşabilecek temel sorulara doğru kaynaklardan cevap bulabilmelerine imkân tanınması açısından önem arz edeceği söylenebilir. 


\section{Kaynakça}

Adıgüzel, Mehmet. “Kur’ân Öğretim Metotları ve Öğreticilik Vasıfları"” Atatürk Üniversitesi İlahiyat Fakültesi Dergisi. 2003, sy.19, s. 193-217.

Ata, Mehmet Mahfuz. “Kurân Öğretim Yöntem ve Teknikleri Problem ve Çözüm Yolları.” Süleyman Demirel Üniversitesi İlahiyat Fakültesi Dergisi. 2013, sy. 30, s. 167-189.

Ayhan, Halis. Türkiye’de Din Eğitimi. İstanbul: Değerler Eğitim Merkezi, 2004.

Başkurt, İrfan. Din Eğitimi Açısından Kurân Öğretimi ve Yaz Kurân Kursları. İstanbul: Değerler Eğitim Merkezi, 2007.

Bayraktar, Mehmet Faruk. Eğitim Kurumu Olarak Kurân Kursları Üzerine Bir Araştırma. İstanbul: Yıldızlar Matbaas1, 1992.

-------..'Yaz Kur’ân Kurslarında Yapılan Eğitim-Öğretim Üzerine Düşünceler.” Yaz Kurân Kursları Sempozyumu (09-11 Temmuz 2010). Erzurum: Tortum Müftülüğü, ts, s. 32-41.

el-Buhârî, Muhammed b. İsmail. el-Câmiu’s-sahîh (nşr. Şuayb el-Arnaût - Âdil Mürşid). I-V, Beyrut: erRisâletü'l-âlemiyye, 1432/2011.

Can, Abdullah. SPSS ile Bilimsel Araştırma Sürecinde Nicel Veri Analizi. Ankara: Pegem Akademi, 2016.

Çollak, Fatih. "Kur'ân-1 Kerîm Öğretim Teknikleri." Etkili Din Öğretimi (ed. Şaban Karaköse). İstanbul: Türkiye İlahiyat Tedrisatına Yardım Eden Dernekler Federasyonu, 2010, s. 515-518.

Dam, Hasan. "Yetişkinlere Göre Yetişkin Din Eğitimi.” Değerler Eğitimi Dergisi. 2003, I, sy. 4, s. 31-54.

Eğin, Osman. "Kurân Öğretiminde Problemler ve Çözüm Önerileri." Etkili Din Öğretimi (ed. Şaban Karaköse). İstanbul: Türkiye İlahiyat Tedrisatına Yardım Eden Dernekler Federasyonu, 2010, s. 601-605.

Halil Hasan, Ömer. "Kur'ân-1 Kerîm Öğretimi”. (trc. Yusuf Alemdar). Cumhuriyet Üniversitesi İlahiyat Fakültesi Dergisi. 2004, VIII, sy.1, s. 261-291.

Işı1k, Emin. “Tarihi Gelişimi İçinde Kur’ân Öğretimi.” Kurân Kurslarında Eğitim, Öğretim ve Verimlilik. İstanbul: İslami İlimler Araştırma Vakfı, 2000, s. 65-69.

Karaçam, İsmail. "Kurân Öğretim Metodunun Ana Çizgileri.” Din Öğretimi ve Din Hizmetleri Semineri (810 Nisan 1988). Ankara: Diyanet İşleri Başkanlığı Yayınları, 1991, s. 116-131.

-------Kur'ân-ı Kerîm’in Faziletleri ve Okunma Kaideleri. İstanbul: Marmara Üniversitesi İlahiyat Fakültesi Vakfı Yayınları, 1998.

Karasakal, Şaban. "Yetişkinlere Kısa Sürede Kur’ân Öğretimi, Uygulama Yöntem ve Teknikleri.” Yecder II. Ulusal Din Görevlileri Sempozyumu Cami Merkezli Din Eğitimi (haz. Şadettin Göksu). İstanbul: Sarıgazi Yunus Emre Camii Külliyesi Eğitim ve Kültür Derneği, 2012, s. 113-131.

Kılavuz, M. Akif. “Kur’ân Kursları ve Yetişkin Din Eğitimi.” Etkili Din Öğretimi (ed. Şaban Karaköse). İstanbul: Türkiye İlahiyat Tedrisatına Yardım Eden Dernekler Federasyonu, 2010, s. 121-166.

Koç, Ahmet. “Kur’ân Kurslarında Din Eğitimi.” Din Eğitimi (ed. Mustafa Köylü - Nurullah Altaş). İstanbul: Ensar Neşriyat, 2014, s. 375-405.

------."Kurân Kurslarında Eğitim ve Verimlilik.” Etkili Din Öğretimi (ed. Şaban Karaköse). İstanbul: Türkiye İlahiyat Tedrisatına Yardım Eden Dernekler Federasyonu, 2010, s. 499-514.

-------."Yaz Kurân Kursları Üzerine Bir Araştırma.” Diyanet İlmi Dergi. 2011, XLVII, sy. 2, s. 7-52.

Korkmaz, Mehmet. "Öğretici Görüşlerine Göre Yaz Kurân Kurslarının Sorunları (Kayseri Örneği) .” Bilimname. 2011, XXI, sy. 2, s. 129-158.

Kulat, Mehmet Ali. Türkiye’de Toplumun Dine ve Dini Değerlere Bakışı. Ankara: Mak Danışmanlık, 2017.

Kurt, Yaşar. "Kur'ân Öğretimi ve Caminin Kurân Öğretimindeki Yeri." EKEV Akademi Dergisi. Yaz 2003, VII, sy. 16, s. 103-120. 
Miral, Mikail. “Üç Günde Hızlı Kurân Öğretim Sistemi.” Yecder II. Ulusal Din Görevlileri Sempozyumu Cami Merkezli Din Eğitimi (haz. Şadettin Göksu). İstanbul: Sarıgazi Yunus Emre Camii Külliyesi Eğitim ve Kültür Derneği, 2012, s. 357-358.

Öcal, Mustafa. “Türkiyede Kur’ân Eğitim ve Öğretiminde Görülen Gelişmeler ve Bir İcazetname Örneği.” Uludağ İlahiyat Fakültesi Dergisi. 2004, XIII, sy. 12, s. 81-140.

Önder, Mustafa. "Yaz Kurân Kurslarında Program, Uygulama ve Mekanın Öğrenci Başarısına Etkisine Dair Bazı Tespit ve Teklifler." Yaygın Din Eğitimi Sempozyumu I (tashih Mustafa Kaya). Ankara: Diyanet İşleri Başkanlığı Yayınları, 2013, s. 337-347.

---_.-Yaz Kurân Kurslarında Dini Öğretmek. Ankara: Gündüz Eğitim ve Yayıncılık, 2009.

Tetik, Necati. "Kur’ân Tilavetinin veya Kıraat İlminin Öğretilmesi Usulleri.” Atatürk Üniversitesi İlahiyat Fakültesi Dergisi. 1990, sy.9, s. 238-244.

et-Tirmizî, Ebû İsa Muhammed b. İsa b. Sevre es-Sülemi. el-Câmiu’s-sahîh / Sünenü’t-Tirmizî (thk. Beşşâr Avvad Ma’rûf). I-VI, Beyrut: Dâru’l-Garbi'l-İslâmî, 1998.

Tunç, İbrahim. “Ülkemizdeki Kur’an Öğretimindeki Metot Hataları, Eksiklikler ve Çözüm Önerileri.” Yecder IV. Ulusal Din Görevlileri Sempozyumu Yeniden Yapılanmanın Eşiğinde Kur’an Kursları (haz. Şadettin Göksu). İstanbul: Sarıgazi Yunus Emre Camii Külliyesi Eğitim ve Kültür Derneği, 2014, s. 61-70.

Yılmaz, Nazif. Kurân-ı Kerîm’i Nasıl Öğretelim?. İstanbul: Değerler Eğitim Merkezi, 2016.

Zengin, Zeki Salih. "Cumhuriyet Döneminde Türkiyede Kur’ân Kurslarının Kurulması ve Gelişmesi." Çukurova Üniversitesi İlahiyat Fakültesi Dergisi. Temmuz-Aralık 2011, XI, sy. 2, s. 1-24.

-----.. "Tarihi Süreç İçerisinde Kur'ân Öğretimi.” Yaz Kurân Kursları Sempozyumu (09-11 Temmuz 2010). Erzurum: Tortum Müftülügü, ts. s. 9-20.

http://www.dunyabulteni.net/servisler/haberYazdir/123567/haber (erişim tarihi: 11.04.2015)

https://www.haberler.com/resimli-hafiza-yontemi-ile-3-gunde-kur-an-egitimi-2850117-haberi/ （erişim tarihi: 10.12.2017)

http://www2.diyanet.gov.tr/EgitimHizmetleriGenelMudurlugu/Kur'ânKursuOgretimProgrami/Yaz\%20 Kurân\%20Kurslar\%C4\%B1\%20\%C3\%96\%C4\%9Fretim\%20Program\%C4\%B1\%20-\%202005.pdf (erişim tarihi: 19.05.2017). 
